\title{
Ground Beetles (Carabidae) in the Short-Rotation Coppice Willow and Poplar Plants-Synergistic Benefits System
}

\author{
Natalia Stefania Piotrowska ${ }^{1, *}$, Stanisław Zbigniew Czachorowski ${ }^{1}(\mathbb{D}$ and \\ Mariusz Jerzy Stolarski ${ }^{2}$ (D) \\ 1 Department of Ecology and Environmental Protection, Faculty of Biology and Biotechnology, University of \\ Warmia and Mazury in Olsztyn, Plac Łódzki 3, 10-727 Olsztyn, Poland; stanislaw.czachorowski@uwm.edu.pl \\ 2 Department of Plant Breeding and Seed Production, Faculty of Environmental Management and Agriculture, \\ University of Warmia and Mazury in Olsztyn, Plac Łódzki 3, 10-724 Olsztyn, Poland; \\ mariusz.stolarski@uwm.edu.pl \\ * Correspondence: natalia.piotrowska@uwm.edu.pl
}

Received: 24 October 2020; Accepted: 14 December 2020; Published: 18 December 2020

\begin{abstract}
In a short period, we have observed the rapid expansion of bioenergy, resulting in growth in the area of energy crops. In Europe, willow and poplar growing in short-rotation coppices (SRC) are popular bioenergy crops. Their potential impact on biodiversity has not yet been fully investigated. Therefore, there are many uncertainties regarding whether commercial production can cause environmental degradation and biodiversity impoverishment. One of the aspects examined is the impact of these crops on entomofauna and ecosystem services. The best-studied insect group is ground beetles from the Carabidae family. This work gathers data on biodiversity and the functions of carabids in willow and poplar energy plants. The results of these investigations show that energy SRC plants and Carabidae communities can create a synergistic system of mutual benefits. Willow and poplar plants can be a valuable habitat due to the increased biodiversity of entomofauna. Additionally, SRC creates a transitional environment that allows insect migration between isolated populations. On the other hand, ground beetles are suppliers of ecosystem services and make a significant contribution to the building of sustainable agriculture by pest control, thereby ameliorating damage to field crops.
\end{abstract}

Keywords: willow SRC; energy plants; ground beetles; Carabidae; ecosystem services; invertebrate biodiversity

\section{Introduction}

Currently, in the EU28 (28 European Union countries), the acreage of lignocellulosic plants is estimated to be 50,000 hectares of short-rotation coppices (SRC), mainly willow (Salix spp.) and poplar (Populus spp.) plants [1]. However, their impact on biodiversity remains only partially known [2]. It is considered that treatment for the natural environment differs for different types of energy crops [3-5].

Non-edible lignocellulosic plants, including willow and poplar, are used for heat and power generation and second-generation liquid biofuel production. It is considered that use of lignocellulosic plants can reduce competition with traditional crops for land and water resources [6], especially when grown on marginal land unsuitable for food production [7]. Despite this, many uncertainties exist about the potential impacts of biomass crops on the environment and biodiversity. There is major concern that commercial production can cause environmental degradation, significantly raising the risk of habitat fragmentation, native extinction, and bio-invasion [6]. Some studies report that the large-scale homogeneous landscape of biofuel plantation has resulted in a simplified bio-community and food web, severely damaging ecosystem services and contributing to the decline in the biodiversity, 
in particular in areas of high nature-conservation value [8]. Therefore, although biomass can help as an energy source to reduce the world's reliance on fossil energy and mitigate global warming [9], there is growing concern about the hypothetical disturbances biofuel can have on ecosystems and biodiversity. Accordingly, in this article, we will focus on willow and poplar SRC. The impact of these plantations on abiotic factors is well understood [10-36], but they can also affect the biotope, changing the species composition of plant and animal communities that directly inhabit the cultivation area, as well as adjacent habitats. So far, however, no comprehensive research has been made that fully shows the impact of willow plantations on the natural environment. It is known that in large agrocenoses, the introduction of small environmental patches of energy crops into cultivation can contribute to an increase in landscape mosaicism, significantly reduced by monocultures $[7,37,38]$.

Studies carried out on large-scale monoculture crops show that the decrease in landscape mosaicism causes many adverse changes at all levels of the trophic chain. These changes occur both at the local level, limited to populations living in a given area, and global, affecting the structure of whole biomes. Over the past few decades, a significant decline in total biomass and the diversity of insect clusters has been observed, especially in North America and Europe [39-41]. Recent research has indicated that flying insect biomass decline may be up to $75 \%$ in some areas [42]. The main reasons hypothesized are anthropogenic drivers including land-use change [43,44], transport routes [45-47], environmental pollution, and pesticides [44,48-50] as well as climate changes $[43,44,51,52]$. Since the end of World War II, we have observed great intensification of agriculture and the evolution of the entire agrocenoses. Crop intensification and excessive pesticide use and accompanying processes, such as melioration or cessation of grazing, have led to the degradation of the habitat [53]. Those changes have contributed to the dramatic loss of biodiversity-many organisms have lost their ecological niches because of lack of shelter or other environmental resources, such as nutrition base. Thus, progressive degradation and the breakdown of ecological networks has been observed.

Due to the possibility of negative environmental effects, research has also been carried out on the influence of energy crops on the fauna that inhabits them. These studies have mainly focused on birds [34,54-67], and a smaller number of them concern mammals [60,61,68-72] or invertebrates [73-93]. Experiments have also been carried out to investigate the differences between biodiversity in woody crops and herbaceous perennial crops and grasses, such as, e.g., Virginia mallow or miscanthus [94]. The most investigated insect group in energy crops are carabids, the largest family of adephagan beetles (Coleoptera: Carabidae) [95,96]. So far, more than 40,000 species of ground beetles have been described, including more than 2700 in Europe and over 2000 in North America [97]. Due to their high plasticity, ground beetles have acquired a wide variety of habitats. This group includes eurytopic (ubiquitous), forest (occurring in wooded environments), open area (found in fields and meadows), coastal (associated with wetlands and banks of waters), and peat bog species. They differ in preference regarding humidity of environment, development cycle, size, and eating habits. Due to the above, Carabidae can be divided into five main groups: large predatory species (body length over $12 \mathrm{~mm}$ ), medium predatory species (5-12 mm), small predatory species $(<5 \mathrm{~mm})$, hemizoophages (half-herbivorous), and phytophages (herbivorous) $[85,86,92,98,99]$. Most beetles in this group are characterized by a high level of predation. Although a diversified forest ecosystem is abundant in factors reducing the presence of phytophages, highly specialized agrocenoses are exposed to an excessive increase in the number of pests. As a result, in addition to anthropogenic factors, beetles from the Carabidae family are one of the main groups that contribute to the control of the pest population. Moreover, their services are not limited to SRC but are also provided to adjacent crops, which plays an important role in sustainable agriculture [100]. Accordingly, the role they are playing in ecological services cannot be underestimated.

The dominance structure in the Carabidae population may be a reflection of the habitat conditions [92]. Sharpening the structure of dominance can be considered a result of destructive factors existing in the environment $[14,101]$. Meanwhile, in stable habitats with the correct structure, smooth transitions are observed between the gradually decreasing percentages of species from individual groups [86]. Similarly, the trophic structure of the carabid population changes depending on the state 
of their living environment. Previously, the presence of large zoophages was considered the most desirable [102], but now the important role of herbivorous species has also been emphasized [103,104].

According to research by [105] in highly intensified agrocenoses, large zoophages are replaced by smaller predatory beetles, and as the pressure increases, the proportion of granivorous carabids increases in the grouping. However, these studies were carried out for meadows and arable fields, and similar works for woodland habitats such as poplar and willow crops are lacking. Therefore, more investigations should be done to estimate this factor for SRC $[92,105]$. Carabidae were chosen as the subject of this review for several reasons:

- $\quad$ As a well-known group of epigeic insects, they can be treated as a monitoring group;

- They play an important role, providing valuable ecosystem services for willow plantations and adjacent crops;

- Compared to other insect groups for which the amount of data is negligible, there are more studies for Carabidae clusters, allowing for analysis.

The novelty of this work is that it show a new view on SRC plantations as environmental islands-areas that can be refugia and environmental corridors for endangered populations. The purpose of this work is not only to show the diversity of entomofauna but also to draw attention to the relationship between the habitat of Carabidae and the shape of their population and their ecologic function, investigations of which have not been extensively developed so far. This will allow a better understanding of the role not only of the ground beetles themselves, as a group providing ecosystem services, but also of the entire complex environment of the energy willow plantation.

\section{Materials and Methods/Data Collection and Selection}

This review presents the most important studies on carabids in energy willow and poplar plantations, mainly in Central Europe. The areas covered are presented in Figure 1.

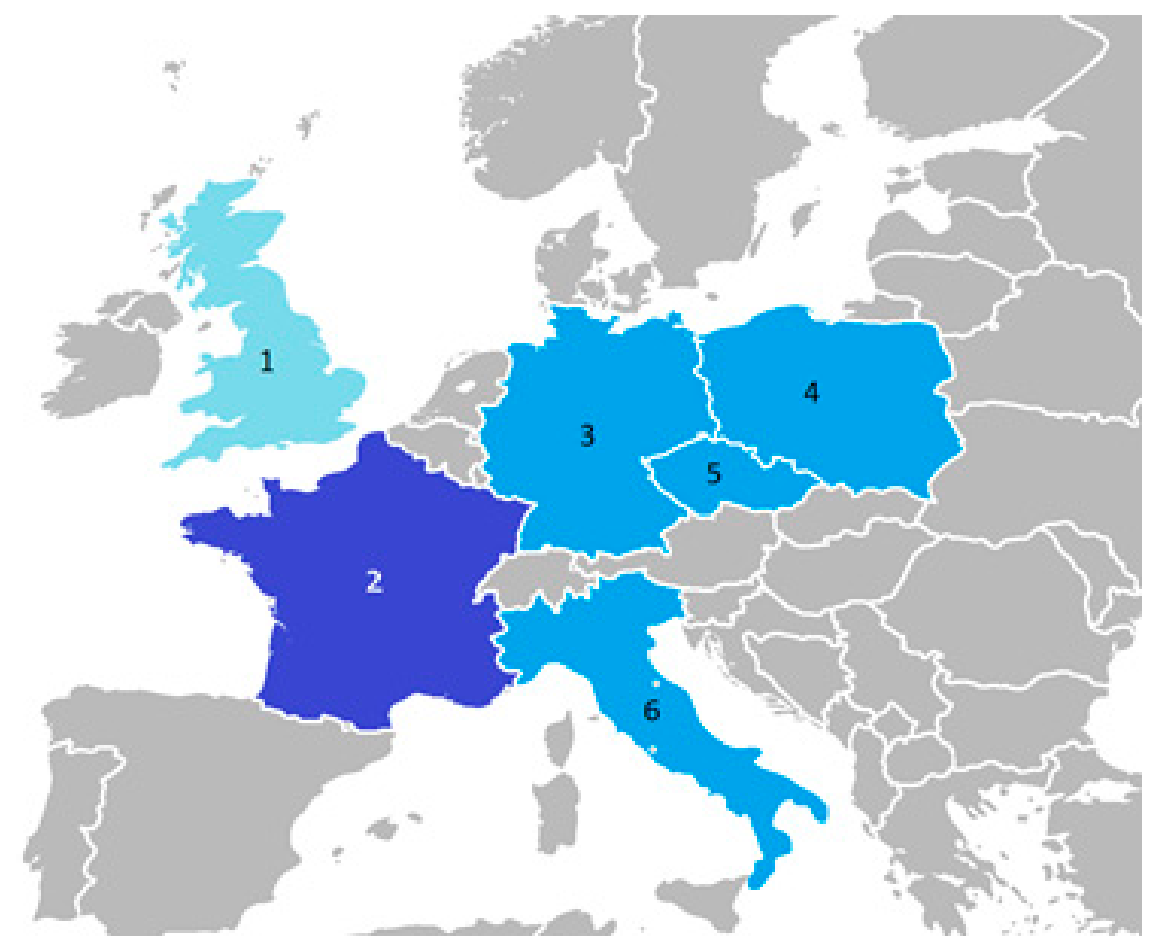

Figure 1. Countries for which original research works on Carabidae beetle fauna on poplar and willow plants were available in searched databases (1-Great Britain, 2-France, 3-Germany, 4-Poland, 5-Czech Republic, 6-Italy; light blue-works used in the study; blue-works used as well not used in the study; dark blue-works not used in the study). 
Materials were acquired from articles published in English, German, and Polish. As the study materials, we used proceedings papers, original research studies, and review articles published between 1950 and 2020, mostly concerning plantations located in Europe. The research was conducted in three scientific databases: International Web of Science, Scopus, and CEON Biblioteka Nauki. In the final database, which is an information source of science papers published only in Polish periodicals, the searched keywords were: "wierzba Carabidae", "wierzba owady epigeiczne", "wierzba biegaczowate", "wierzba bioróżnorodność owadów", "wierzba bioróżnorodność entomofauny", "wierzba entomofauny", "wierzba owadów", "wierzba biegaczowatych", "wierzby biegaczowatych", "wierzby owadów epigeicznych", "wierzby Carabidae", "wierzby bioróżnorodność owadów", "wierzby bioróznorodność entomofauny", "wierzby entomofauna", "wierzby biegaczowate", and "wierzby owady epigeiczne". Meanwhile, from the Web of Science database, the material was acquired by searching for the following words: "energetic willow Carabidae", "energy crops Carabidae", "Salix viminalis Carabidae", "short rotation coppice Carabidae", "energetic poplar Carabidae", "energetic willow ground beetles", "energy crops ground beetles", "Salix viminalis ground beetles", "short rotation coppice ground beetles", "energetic poplar ground beetles", "energetic willow epigeic insects", "energy crops epigeic insects", "Salix viminalis epigeic insects", "short rotation coppice epigeic insects", "energetic poplar epigeic insects", "energetic willow insects biodiversity", "energy crops insects biodiversity", "Salix viminalis insects biodiversity", "short rotation coppice insects biodiversity", and "energetic poplar insects biodiversity". In Scopus, to restrict the search, we used words such as: "energetic willow Carabidae", "Salix viminalis Carabidae", "short rotation coppice Carabidae", "energetic poplar Carabidae", "energetic willow ground beetles", "Salix viminalis ground beetles", "short rotation coppice ground beetles", "energetic poplar ground beetles", "energetic willow epigeic insects", "Salix viminalis epigeic insects", "short rotation coppice epigeic insects", "energetic poplar epigeic insects", "energetic willow insects biodiversity", "Salix viminalis insects biodiversity", "short rotation coppice insects biodiversity", and "energetic poplar insects biodiversity".

In both databases, records were searched in all fields. In the Web of Science, our investigations included all collections. To broaden the results of the research, the "References" sections of the research articles used to prepare this review were studied, and relevant articles, if were not previously included, were added to our investigations. Furthermore, similar proceedings were applied to articles found in the Scopus database, where the "cited by" section was used. Most of the articles found were excluded from the analysis due to low relevance and duplications. The exclusion criteria for the selected articles were: no connection with the subject, the articles concerned other species of energy plants, the articles related to animals other than Carabidae, and the articles described plantations from outside of Europe.

The CEON Biblioteka Nauki database showed 58 records, among which only 3 records were selected as related to the topic. The International Web of Science database indicated 77 records, among which 22 were chosen as relevant. The Scopus database yielded the highest number of articles, as many as 5517 records. Due to this, it was decided to narrow down the search area and to reject key phrases containing "energy crops". This reduced the number of records to 458, out of which 24 relevant results were selected.

The articles collected were sorted according to the year of publication and the country of origin (the country was assigned based on the corresponding author). The results are presented in Figures 2 and 3. In the years 1998-2020, 32 articles on Carabidae biodiversity in energy willow and poplar plantations were published. Most of them, as many as 15 items, were published by German authors. Their number is three times higher than that of Polish and British publications. For Czech and Swedish authors, a database search showed two publications each. One publication was found for the Netherlands, Slovakia, and Belgium, respectively. In investigations for years from the 1950s until 1998, the databases did not show any publications described by the keywords used. In 1998, one publication was issued, and another was issued after 9 years, in 2008. An upward trend was observed for the following years, with 6 publications issued in 2012. For 2013 and 2014, there were 4 publications each. After this year, 
there is a clear decrease in the number of publications-in 2015, no publications were issued, in 2016, two were issued, and in the following years, only one publication per year was issued.

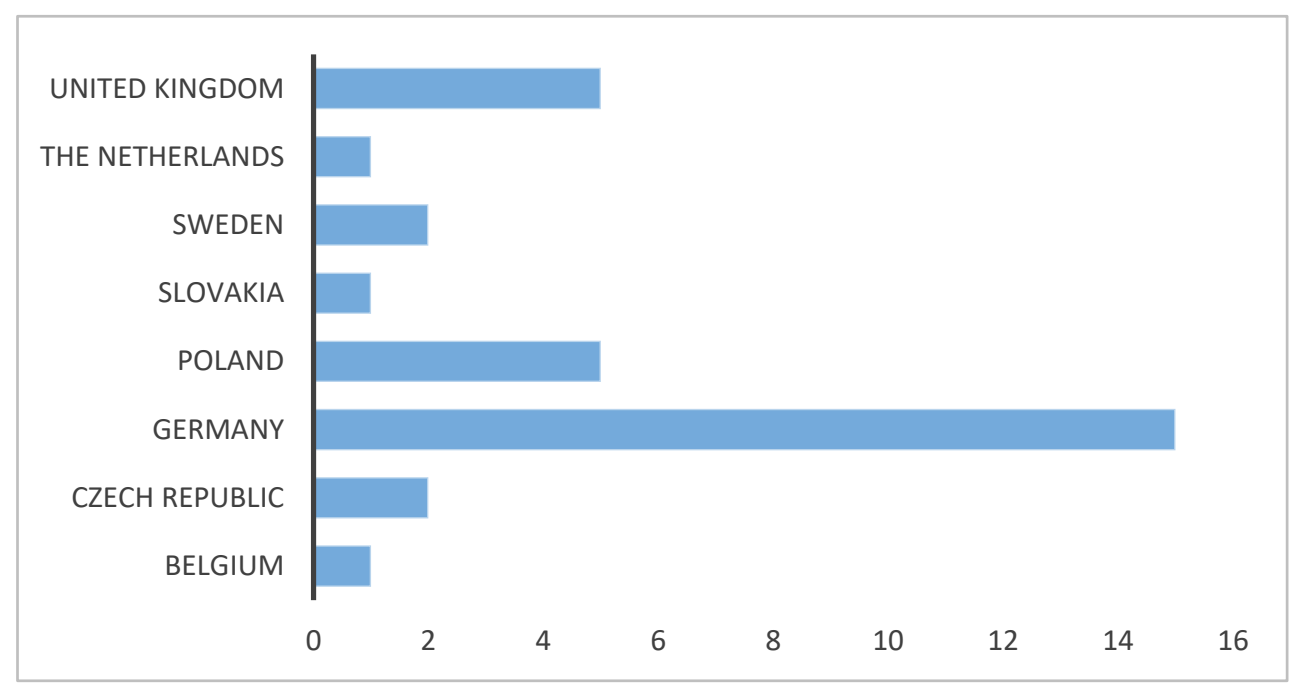

Figure 2. Publications on Carabidae in energy willow and poplar plantations-number per country. Articles found in three scientific databases: International Web of Science, Scopus, and CEON Biblioteka Nauki after discarding unrelated works and duplicated records.

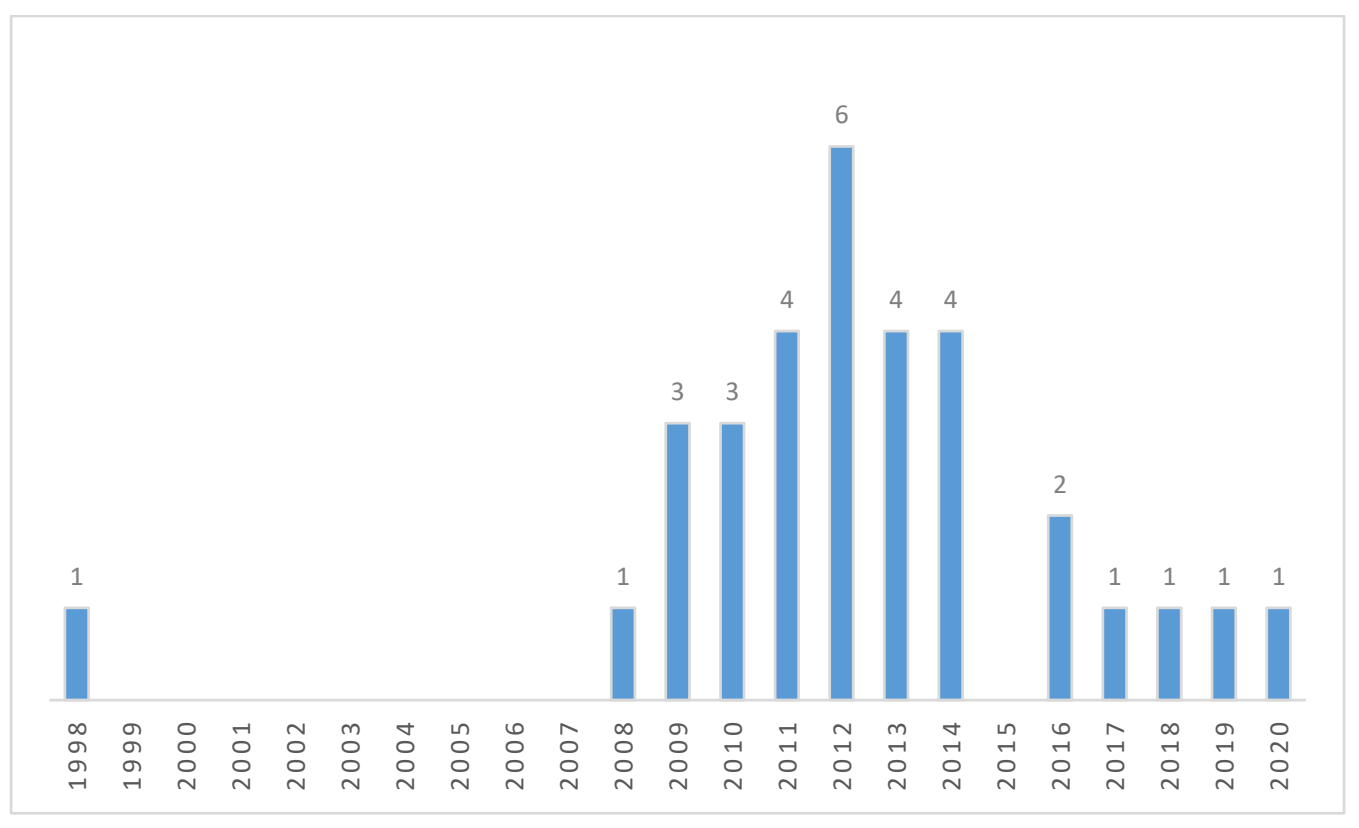

Figure 3. Publications on Carabidae in energy willow and poplar plantations-number per year. Articles found in three scientific databases: International Web of Science, Scopus and CEON Biblioteka Nauki after discarding unrelated works and duplicated records.

From the publications, four articles were selected that contained sufficient data to create an ecological characterization of Carabidae inhabiting the plantations described in them [85-87,92]. This enabled the designation of 12 research areas and the determination of the dominance structure, as well as phenology, hygro- and habitat preference, trophy group and dispersion powers. Energy plants characteristics are described in Table 1. To describe the phenology, hygropreference, trophy group and dispersion powers, individual species were assigned appropriate characteristics, and then their percentage of the total number of species was calculated. To describe the dominance structure based on abundance, species were assigned to different domination classes: eudominants, dominants, 
subdominants, recedents and subrecedents. Both methods were used to describe habitat preference, assessing both the percentage share of individual species in the total pool and the percentage of individuals with given environmental preferences on each of the plantations. Additionally, the number of forest species occurring on each study plot was shown concerning the age of the plantation and the size of the stand. The obtained results are presented in the form of tables and graphs in the Results and Discussion sections. Microsoft Office Excel was used for its design.

Table 1. Research articles that were the basis of this review-plantations characteristic (Local._localization, Plant.—plantation, Years-years of investigation).

\begin{tabular}{|c|c|c|c|c|c|c|c|}
\hline References & Investigated Issues & Local. & $\begin{array}{l}\text { Plant. } \\
\text { Type }\end{array}$ & $\begin{array}{l}\text { Plant. } \\
\text { Age }\end{array}$ & $\begin{array}{l}\text { Canopy } \\
\text { Age }\end{array}$ & $\begin{array}{c}\text { Adjacent } \\
\text { Habitat }\end{array}$ & $\begin{array}{l}\text { Years } \\
\text { Date }\end{array}$ \\
\hline [86] & $\begin{array}{l}\text { 1. Species richness and } \\
\text { diversity, dominance } \\
\text { structure. } \\
\text { 2. Community structure: } \\
\text { trophic, habitat } \\
\text { preference, humidity } \\
\text { preference, development } \\
\text { type. }\end{array}$ & Northeast Poland & willow & $\begin{array}{c}8-9 \\
\text { years }\end{array}$ & $\begin{array}{l}\text { Not } \\
\text { given }\end{array}$ & none & 2004-2005 \\
\hline [85] & $\begin{array}{l}\text { 1. Species richness and } \\
\text { diversity, dominance } \\
\text { structure. } \\
\text { 2. Community structure: } \\
\text { trophic, habitat } \\
\text { preference, humidity } \\
\text { preference, development } \\
\text { type. }\end{array}$ & Northeast Poland & willow & $\begin{array}{l}1 \text { to } 3 \\
\text { years }\end{array}$ & $\begin{array}{l}1 \text { to } 3 \\
\text { years }\end{array}$ & none & 2005-2006 \\
\hline [87] & $\begin{array}{l}\text { 1. Species composition } \\
\text { and abundance of ground } \\
\text { beetles inhabiting } \\
\text { unexploited willows } \\
\text { plantation. } \\
\text { 2. Population ecological } \\
\text { characteristic and } \\
\text { dominance structure. } \\
\text { 3. Margalef's index, } \\
\text { Shannon' diversity, } \\
\text { Evenness H/log(N) } \\
\text { Pielou. }\end{array}$ & Southeast Poland & willow & $\begin{array}{l}\text { not } \\
\text { given }\end{array}$ & $\begin{array}{l}8 \text { and } 9 \\
\text { years }\end{array}$ & none & 2011-2012 \\
\hline [92] & $\begin{array}{l}\text { 1. Species richness and } \\
\text { diversity, dominance } \\
\text { structure. } \\
\text { 2. The similarity to } \\
\text { natural woodlands. }\end{array}$ & Po Valley, Italy & poplar & $\begin{array}{l}1 \text { to } 10 \\
\text { years }\end{array}$ & $\begin{array}{l}\text { not } \\
\text { given }\end{array}$ & $\begin{array}{c}\text { natural } \\
\text { woods, crops: } \\
\text { maize, } \\
\text { tobacco }\end{array}$ & 1989-1999 \\
\hline [102] & $\begin{array}{l}\text { 1. Influence of the } \\
\text { plantation vicinity and } \\
\text { anthropogenic factors on } \\
\text { Carabidae assemblages. } \\
\text { 2. The structure of beetle } \\
\text { communities. }\end{array}$ & $\begin{array}{l}\text { South Bohemia } \\
\text { (Czech Republic) }\end{array}$ & willow & $\begin{array}{l}2,4,6 \\
8 \text { years }\end{array}$ & $\begin{array}{l}\text { not } \\
\text { given }\end{array}$ & $\begin{array}{l}\text { Field with a } \\
\text { stream; pond, } \\
\text { field, alder } \\
\text { trees and } \\
\text { meadow; } \\
\text { pasture, field, } \\
\text { cultural } \\
\text { forest; }\end{array}$ & 2007 \\
\hline
\end{tabular}


Table 1. Cont.

\begin{tabular}{|c|c|c|c|c|c|c|c|}
\hline References & Investigated Issues & Local. & $\begin{array}{l}\text { Plant. } \\
\text { Type }\end{array}$ & $\begin{array}{l}\text { Plant. } \\
\text { Age }\end{array}$ & $\begin{array}{l}\text { Canopy } \\
\text { Age }\end{array}$ & $\begin{array}{c}\text { Adjacent } \\
\text { Habitat }\end{array}$ & $\begin{array}{l}\text { Years } \\
\text { Date }\end{array}$ \\
\hline [81] & $\begin{array}{l}\text { 1. Comparison of how } \\
\text { predation processes by } \\
\text { ground arthropods varied } \\
\text { between short rotation } \\
\text { coppice (SRC) willow } \\
\text { bioenergy plantations } \\
\text { and alternative land-uses: } \\
\text { arable and set-aside. } \\
\text { 2. Predation pressure } \\
\text { investigations: prey } \\
\text { removal assay coupled } \\
\text { with pitfall traps and } \\
\text { direct searches }\end{array}$ & $\begin{array}{l}\text { North } \\
\text { Nottinghamshire, } \\
\text { England }\end{array}$ & willow & $\begin{array}{l}1 \text { to } 10 \\
\text { years }\end{array}$ & $\begin{array}{l}1 \text { to } 9 \\
\text { years }\end{array}$ & $\begin{array}{l}\text { set-aside, } \\
\text { arable }\end{array}$ & 2008 \\
\hline [88] & $\begin{array}{l}\text { 1. Simpson biodiversity } \\
\text { index, evenness, level of } \\
\text { anthropogenic influence } \\
\text { 2. The influence of the } \\
\text { length of rotation on } \\
\text { biodiversity parameters; }\end{array}$ & $\begin{array}{l}\text { Peklov, Czech } \\
\text { Republic }\end{array}$ & poplar & 9 years & $\begin{array}{l}1,3,6 \\
\text { years } \\
\text { rotations }\end{array}$ & none & 2003-2008 \\
\hline [89] & $\begin{array}{l}\text { 1. Taxonomy and } \\
\text { identification. } \\
\text { 2. Species traits and } \\
\text { categorization. } \\
\text { 3. Habitat preferences. } \\
\text { 4. Endangered species. } \\
\text { 5. Dispersal of forest } \\
\text { species; corridor function. } \\
\text { 6. Species traits } \\
\text { concerning age of the } \\
\text { SRC versus age of the } \\
\text { SRC standing crop. } \\
\text { 7. Factors influencing } \\
\text { SRC biodiversity } \\
\text { functions. }\end{array}$ & $\begin{array}{c}\text { Germany } \\
\text { (different sites) } \\
\text { and the Czech } \\
\text { Republic }\end{array}$ & $\begin{array}{l}\text { willow } \\
\text { poplar }\end{array}$ & $\begin{array}{l}1 \text { to } 23 \\
\text { years }\end{array}$ & $\begin{array}{l}1 \text { to } 9 \\
\text { years }\end{array}$ & different & Meta-study \\
\hline
\end{tabular}

\section{Results}

Based on the data analysis, presented in Figure 4, the predominance of Carabidae species preferring the environment of open areas was found. The comparison of Figure 5 and Table 2 showed that the percentage share of species preferring open areas is independent of the age of the plantation, while its dependence on the age of the stand seems impossible to assess due to insufficient data. However, their share appears to decline as the age of the canopy increases. Species preferring open areas also constituted the most numerous group in terms of the number of individuals in a given population, which is presented in Figure 5. This tendency occurred on most plantations, both willow [85-87] and poplar [92]. Species with unknown habitat preference constituted less than $15 \%$ of all recorded species. On three plantations, the niche of open ground species was occupied by eurytypical species. The share of forest species was greater, at over 18 percent (Figure 4). The number of forest species depending on the age of the plantation and the age of the canopy is presented in Table 2. In some plantations, there was a visible predominance of ground beetles representing forest species, which, however, was not correlated with the age of the plantation. Unfortunately, the amount of data allowing us to assess the influence of the surrounding environment on the number of Carabidae from different ecological groups was insufficient. A similar correlation concerning the age of the stand is impossible to analyze due to the lack of sufficient data, as the analyzed publications lack information enabling its determination. The number of peatland species was less than $10 \%$ that of all species collected, and the number of individuals with this preference was even lower. 


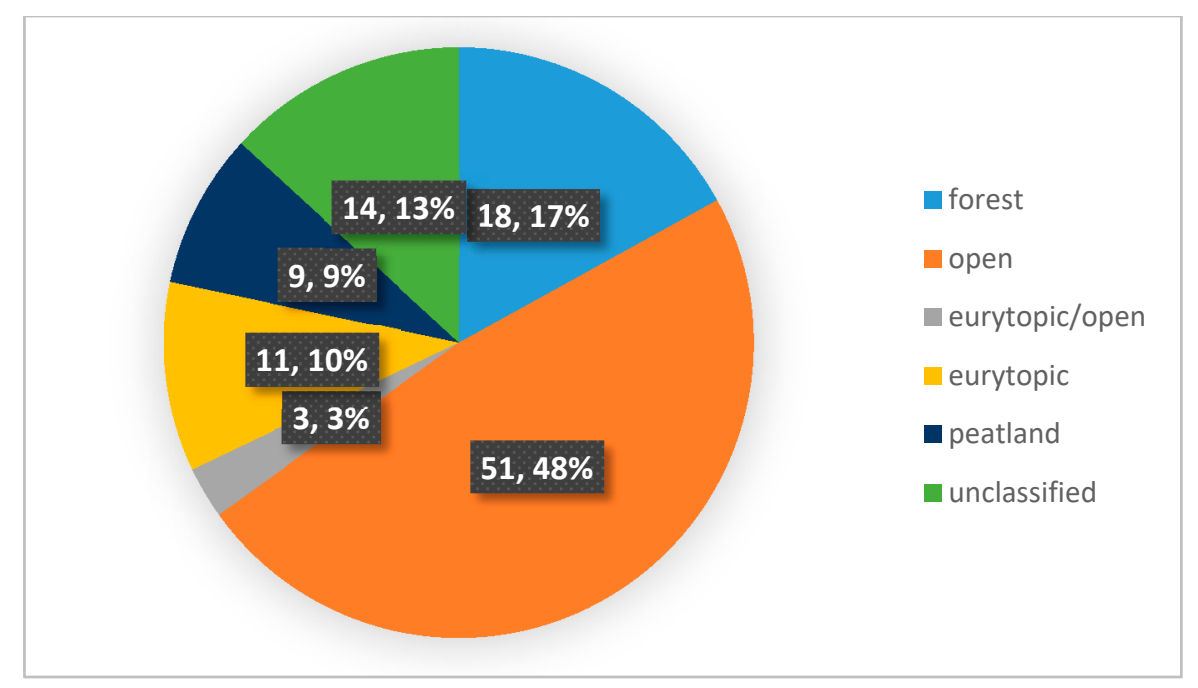

Figure 4. Percentage distribution of Carabidae species found in selected willow and poplar plantations depending on environmental preferences. The diagram was made based on selected publications, including data on the ecological characteristics of Carabidae communities inhabiting investigated plants.

Table 2. The number of Carabidae species preferring the forest environment, taking into account the number of species in the classes of eudominants (ED) and dominants (D). The table was made based on selected publications, including data about the ecological characteristic of Carabidae communities inhabiting investigated plants (W1, W2 and unmarked-willow plots; P1-P4-poplar plots).

\begin{tabular}{|c|c|c|c|}
\hline Investigated Plots and Year of Investigation & $\begin{array}{l}\text { Plantation } \\
\text { Age (Years) }\end{array}$ & $\begin{array}{l}\text { Canopy Age } \\
\text { (Years) }\end{array}$ & $\begin{array}{l}\text { Number of Forest Species } \\
\text { (including ED and D) }\end{array}$ \\
\hline [86] 2004 & 8 & Not given & 5 (1 ED) \\
\hline [86] 2005 & 9 & Not given & $4(2 \mathrm{ED})$ \\
\hline [85] 2005 W1 & 2 & 2 & $2(2 \mathrm{ED})$ \\
\hline [85] $2006 \mathrm{~W} 1$ & 3 & 3 & 2 \\
\hline [85] $2005 \mathrm{~W} 2$ & 1 & 1 & $2(2 \mathrm{ED})$ \\
\hline [85] $2006 \mathrm{~W} 2$ & 2 & 2 & $2(1 \mathrm{ED})$ \\
\hline [87] 2011 & Not given & 8 & 7 (1 ED) \\
\hline [87] 2012 & Not given & 9 & 5 (1 ED) \\
\hline [92] 1989 P1 & 2 & Not given & 5 \\
\hline [92] 1999 P2 & 6 & Not given & $3(1 \mathrm{ED}, 1 \mathrm{D})$ \\
\hline [92] 1999 P3 & 6 & Not given & $2(1 \mathrm{D})$ \\
\hline [92] $1991 \mathrm{P} 4$ & 10 & Not given & 4 (2 ED) \\
\hline
\end{tabular}




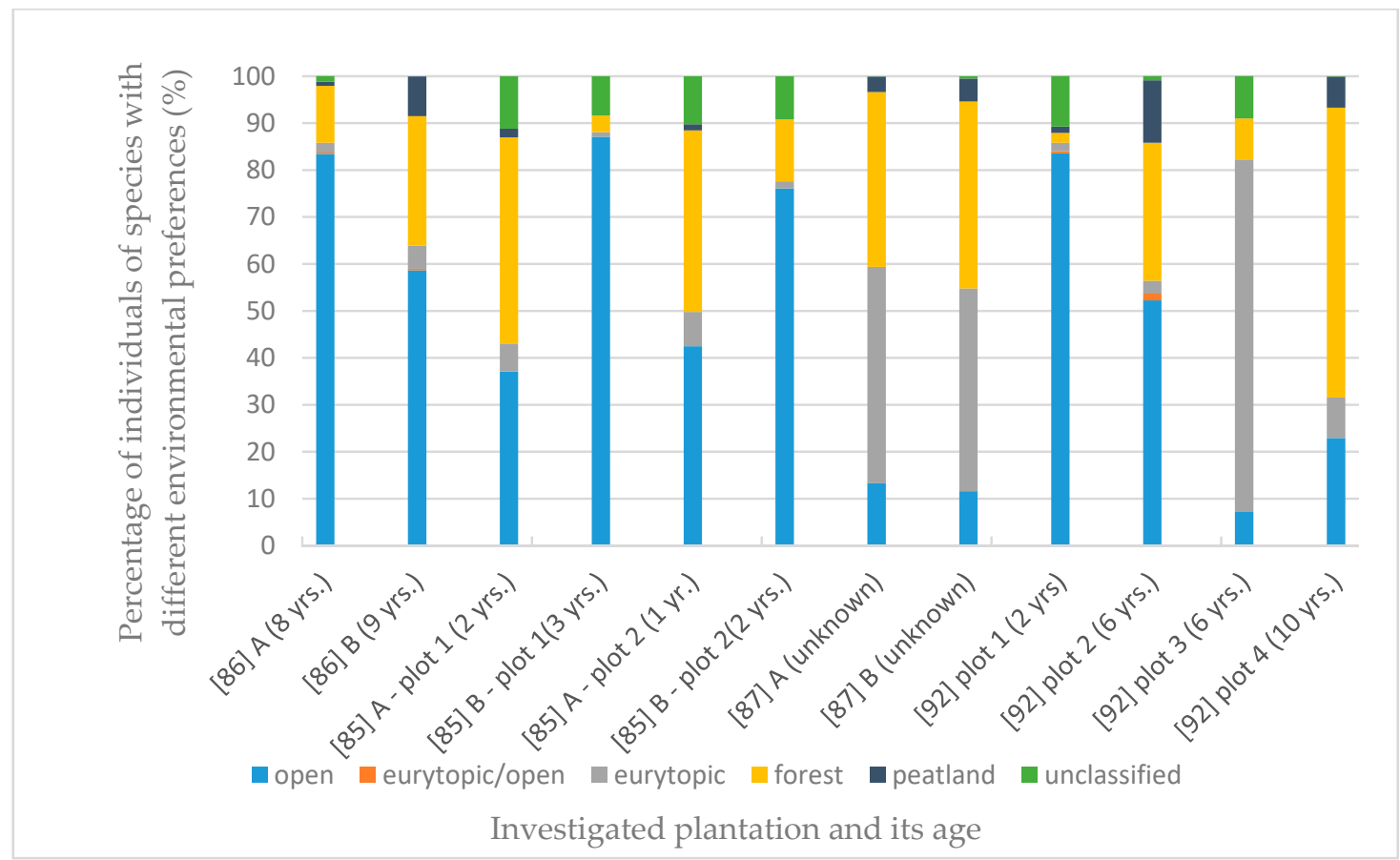

Figure 5. Habitat preferences vs. plantation age. Percentage of individuals of species with different environmental preferences depending on the age of the plantation (in brackets). The last four plots, studied by [92], are poplar crops. The remaining 8 are willow plantations [85-87], A-first year of investigations, $\mathrm{B}$ - second year of investigations.

A wider assessment of the carabid population in the SCR plantation, taking into account the structure of dominance, trophic structure, and species properties, indicated the predominance of poorly specialized species with wide environmental tolerance. Data analysis showed that the number of brachypterous species was smaller than that of macropterous ones (Figure 6), comprising only one fifth of all examined species. Macropterous species, characteristic for disturbed environments, constituted $64 \%$ of the investigated population. Similarly, species with spring biology were significantly more numerous than autumn biology ones, which are characteristic of well-balanced environments (Figure 7). The compilation of the collected data showed that the dominance structure of the studied populations was poorly balanced. In 11 out of 12 assessed plots, the number of eudominants predominated, amounting to over $60 \%$ in eight cases, and over $70 \%$ of all specimens in five cases. (Figure 8). Granivorous species predominated, followed by small and large zoophages (Figure 9). In terms of hygropreference (Figure 10), mesophiles were the most numerous. A large group was also species with undefined hygropreference. Poor Carabidae specialization may indicate an imbalance in the environment in which they live. On the other hand, there were no sharp transitions between individual trophic groups, while the percentage of large zoophages was average. This proves that even though the plantation environment is subject to intensive changes, it is possible to maintain a sustainable biocenosis there. 


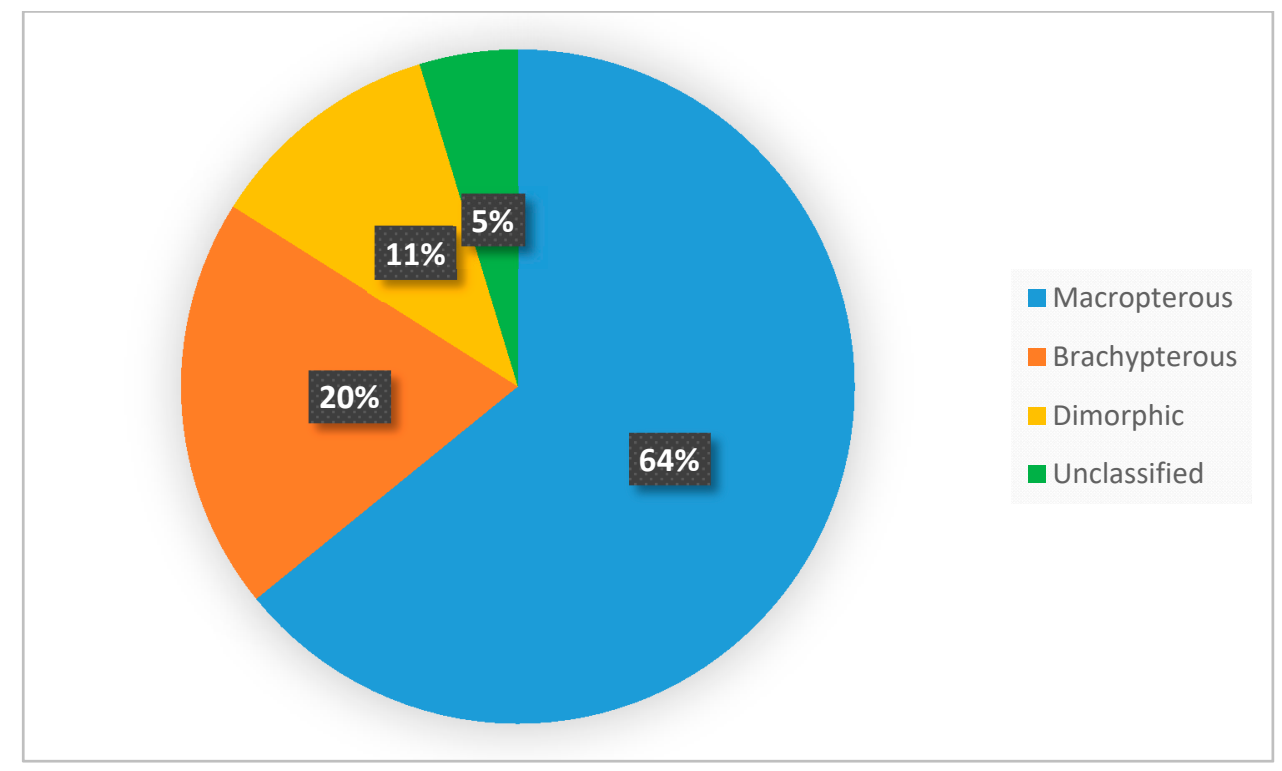

Figure 6. Percentage distribution of Carabidae species with different dispersibility. This diagram was made based on selected publications, including data on the ecological characteristics of Carabidae communities inhabiting the investigated plants.

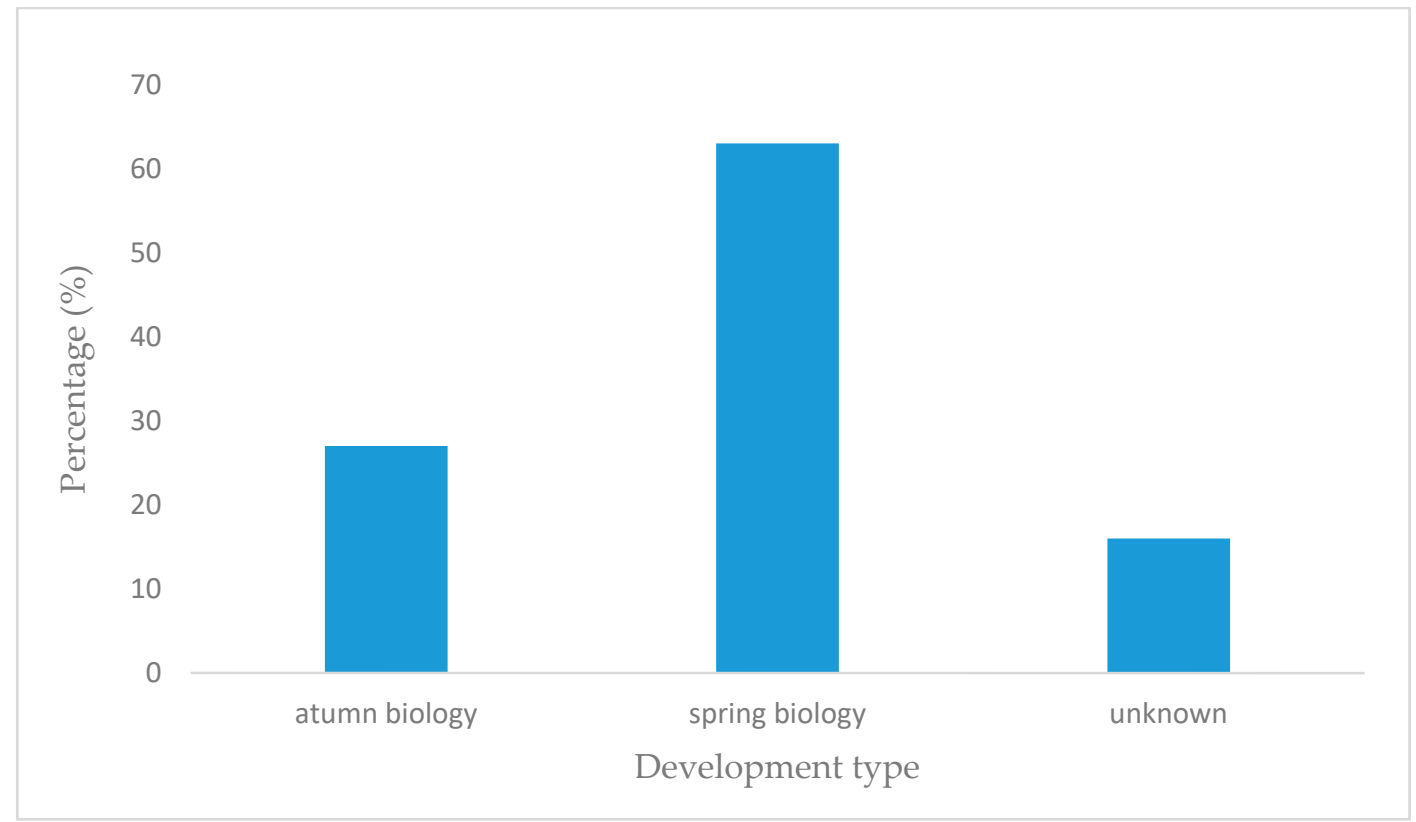

Figure 7. Per cent of Carabidae species with a different development type. This phenology diagram was made based on selected publications, including data on the ecological characteristic of Carabidae communities inhabiting the investigated plants. 


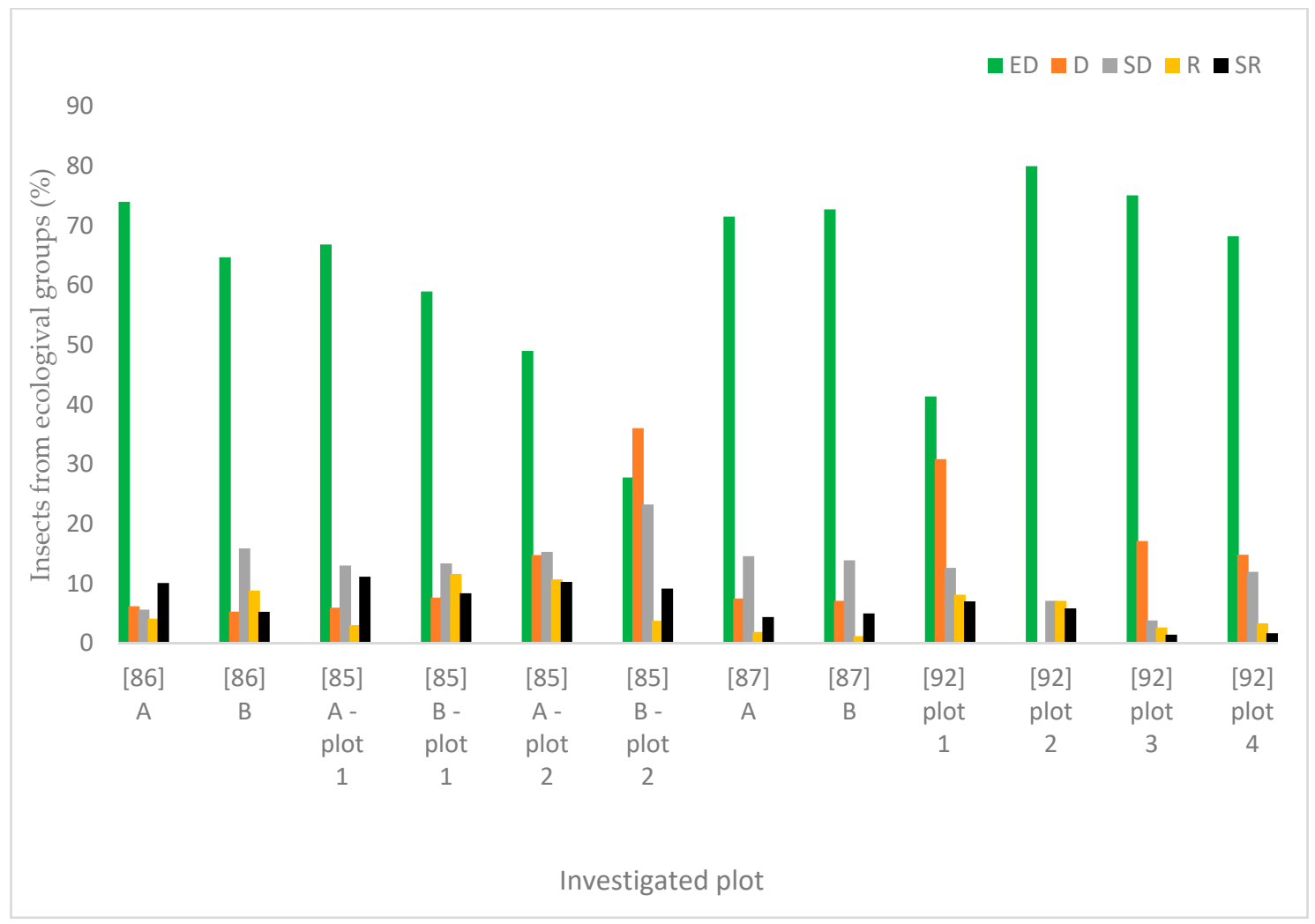

Figure 8. Structure of dominance in the Carabidae population based on the percentage of insects from particular groups (ED-eudominants; D-dominants; SD-subdominants; R-recedents; SR-subrecedents). This diagram was made based on selected publications, including data on the ecological characteristics of Carabidae communities inhabiting the investigated plants. (A-first year of investigations, B-second year of investigations).

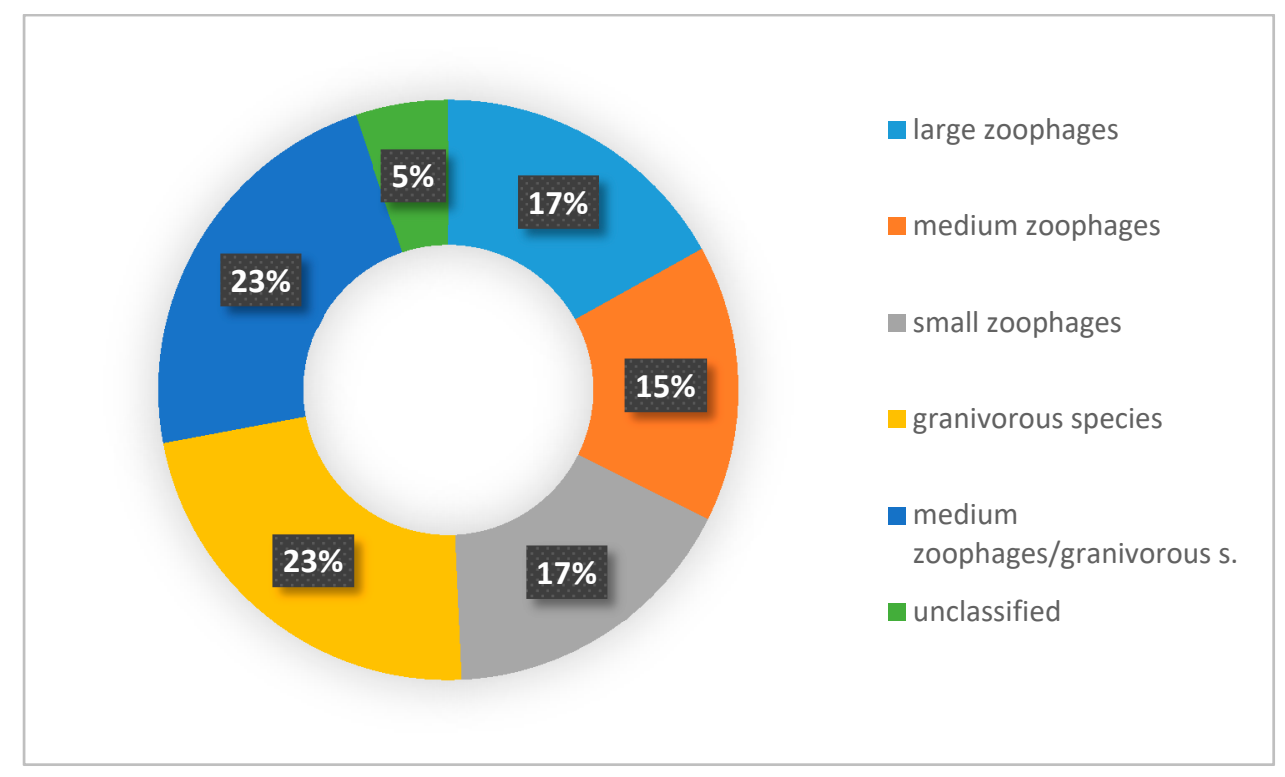

Figure 9. Percentage of Carabidae species from different trophy groups. This diagram was made based on selected publications, including data on the ecological characteristics of Carabidae communities inhabiting the investigated plants. 


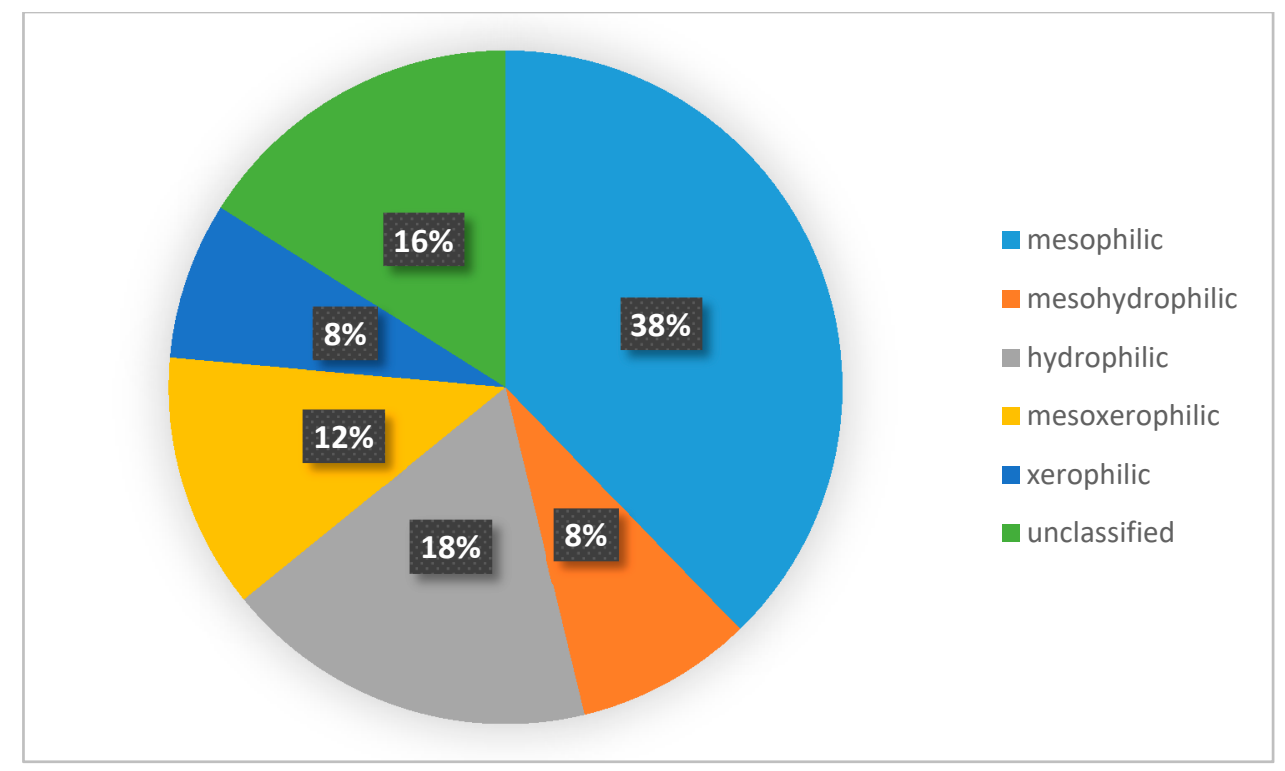

Figure 10. Per cent of Carabidae species with a different hygropreference. Diagram was made based on selected publications, including data about the ecological characteristic of Carabidae communities inhabiting the investigated plants.

\section{Discussion}

While the impact of willow and energy poplar plantations on abiotic factors is well-studied, there is a lack of comprehensive, multi-faceted research on the impact of plantations on biotic factors. Another problem is the lack of a homogeneous testing methodology. This makes research results difficult to interpret and compare with results obtained by other scientists. Of the many studies conducted, there were varying results, depending on the study region, the establishment phase of the SRC, its characteristics and its surroundings. Factors shaping SRC nature are adjacent land, terrain and water relations in the area where the plantation is located, the size and spatial configuration of the plantation itself, plantation age, the length of the production cycle and its phase (canopy age), and the willow strains planted. Due to a large number of variables, these results can be difficult to interpret. So far, no comprehensive research has been carried out to describe the roles of all specific factors. The impact of particular plantation features on the Carabidae populations inhabiting them is described below.

\subsection{Factors Affecting Biodiversity}

\subsubsection{Rotation Length and Canopy Age vs. Plantation Age}

It was found that, in general, agricultural fields and forests were both characterized by greater species richness (estimated by the species number) than willow and poplar SRC [89]. However, it was noticed that the strictly quantitative indicator "species richness" (species numbers) is only weakly correlated with qualitative biodiversity targets such as rare and endangered or specialized species $[89,96]$.

A factor strongly influencing the biodiversity values of SRC regarding stenotopic species is rotation length. Wegner et al. [88] hypothesized that longer rotations may favor "ubiquitous" versus "stenotopic" species in terms of anthropogenic influence being less flexible. Their research indicated that poplar plantations are the habitat preferred mainly by non-specialized species, whereas increased inflow of adaptable species is observed after the harvests and is connected with differences in the re-growth dynamics (steam sprouting is slower in older plantations, which have the characteristics of an open vegetation site during this period) $[88,89]$. This seems to corroborate the data from articles collected by Müller-Kroehling et al. [89], indicating that in the majority of cases, only very young SRC 
in the establishment phase can provide an ephemeral pioneer habitat with a particular value for species protection [106]. Harvesting can at least partially renew a habitat function for open-habitat species by creating favorable conditions for the development of the herbaceous plant. Creating fallow-like conditions, they can act as a refugium for short-lived, open habitat species, especially granivorous or polyphagous species for which older SRC have a limited conservation value [89,92]. The analyzed data showed that not fully established plantations are a habitat for a high abundance of seed-eating species, the number of which diminishes with the age of the plantation. Similarly, in freshly cut stands, the number of granivorous species was higher, which means that harvesting promotes population increase for some of them, e.g., Agonum sexpunctatum, Amara plebeja, A. similata, A. aenea, Anisodactylus binotatus, Harpalus affinis, Pseudoophonus. rufipes, Poecilus cupreus and P. versicolor, which are eurytopic, less specialized species. Furthermore, it was proven that there is a group of species which prefers openings and seams of SRC than strictly open habitats such as fields and grassland, particularly in highly impoverished landscapes with few ecotone habitats, as was shown for Carabus auratus [89]. Therefore, many authors found later rotations of SRC as having a lower biodiversity value, hence they were inhabited mostly by species assemblages dominated by common, eurytopic species $[89,96]$.

Similarly, Müller-Kroehling et al. [89] found that the abundance of the red-listed species is negatively correlated with the age of the plantation, while for the age of stand, no significant trend was observed. Meanwhile, in-depth analysis showed that while federally red-listed species occurred mostly in the newly established SRC, for the regional lists, the trend is reversed, and the red-listed species were more abundant among older plantations. Additionally, in this case, the longitude of rotation was negatively correlated with the occurrence of the endangered species. This proves that even though willow and poplar plants are uniform regarding their age, they still undergo a directed development and the age of the plantation plays a substantially larger role than the age of the canopy attained after harvesting $[87,89]$. It could also be anticipated that the age of the stand was a significant occurrence factor; surprisingly, the age of the plantation was even strongly positively correlated with this species' presence $[89,96]$. Changes taking place during plantation growth affected microclimatic conditions, depending on other factors from the accompanying plant cover [89,107-109]. Long-established SRC plantations probably provide better soil conditions, including soil moisture and soil particle size distribution, which is important especially for the development of larval carbide forms $[89,92,97,110,111]$. Furthermore, as a refugium for some species endangered at the local scale, SRC may help to increase regional population stability and genetic diversity across the country. Additionally, it was found that the presence of endangered species, for example Abax ovalis, A. carinatus and A. parallelus, Molops elatus and Carabus auratus, was also strongly positively correlated with the proximity of forest. During this research, it was found that a plant with extended time without coppicing can serve as a refugium for forest species, contributing to their protection in the agricultural landscape. Among the collected beetles, in both qualitative and quantitative terms, dendrophile species predominated. Most of them were typically forest species, while ecotone species partly associated with tree stands were also numerous. Articles juxtaposition indicated that more than half of all identified species were characteristic for open areas, which proves the role of the energy willow plantation as a reservoir for these taxa. Such a result was also obtained by Konieczna et al. [87], who examined abandoned plantations. In this work, a large number of beetles characteristic of open areas was also observed. It is worth mentioning that the time for which the investigated plants were not harvested was similar to the period without canopy cutting on EcoSalix plantations [7,112]. Unfortunately, in some publications, significant data describing the surroundings of the plantation and its spatial arrangement as well as determining the method of sampling were lacking. This reduces the possibilities of interpretation of the data obtained. The greatest disadvantage of some works was the missing information about plantation age, which makes it impossible to determine whether the presence of forest species is the result of the canopy or the age of the plantation. 


\subsubsection{Surrounding Area-Environmental Corridors and Islands}

The plantation area is the factor for which the influence has not been fully estimated so far. Larger plantations provide habitats for a greater amount of forest species; however, most of the research was conducted in not very large SRC [89]. Therefore, some authors claimed that large plantations can contribute to a decrease in biodiversity $[96,110,113,114]$. Another factor examined was the surrounding crops. Many of the endangered species are forest species with low dispersal power. Among this group, there are many stenotopic brachypterous species with reduced vestigial wings. Because of the lacking development of the hind wings, they do not have the ability for dispersal flights. Therefore, the distance to the nearest forest is, in some cases, a limiting factor $[89,96,110]$. Additionally, it is worth mentioning that flight ability is a species adaptation often connected with inhabiting a disturbed environment, for example, cultural land [97,110].

In high-land-pressure agricultural landscapes with high fragmentation and a lack of connectivity between individual habitats, strictly forest species can be isolated in forest "islands". According to the island theory, only large habitat patches providing enough resources can serve as a stable environment. On the other hand, vast areas of monocultures and low landscape diversity can lead to species declining, especially stenotopic species or those with high environmental requirements $[115,116]$. One of the main reasons for this is the genetic erosion of the population $[89,96]$. This issue has great importance in the SLOSS (single large or several small) debate [117-119].

It is known that green corridors prevent the isolation of the population and thus the depletion of their genetic pool $[107,108]$. A decrease in the effective population size leads to the disclosure of the negative effects of genetic drift and coalescence, which is more visible in small, isolated populations $[109,111,113,114]$. It leads to an increase in homozygosity and the loss of genetic variability. In extreme cases homogeneity can depress population fitness, general resistance to environmental factors, and flexibility in coping with environmental challenges [109,115]. Therefore, one of the assumptions of sustainable agriculture is to increase the landscape mosaicism. Based on the concept of "Islands biogeography" introduced by McArthur and Wilson [120-125], landscape corridors connecting isolated habitat patches can be applied to the agrocenoses, for example by fallowing or introducing extensive agricultural crops [37,126-128]. Establishing energy willow and poplar crops on lower-class soils or on the marginal land enables one to diversify the use of arable land, maintaining an income for local farmers [7,38]. In this type of area, the additional function of SRC, especially old ones, for forest species is being the corridor habitat $[89,90,129]$. The scope of this role might vary largely regionally according to inhabiting species and environmental factors. It is also worth noting that the effects of climate change will exacerbate the problem of the decline of both epigeic beetles $[52,130]$ as well as insects in general $[43,44,51,131-135]$.

\subsection{Carabidae as Bioindicators and Ecosystem Services Providers}

Determining the characteristics of epigeic beetle assemblies on SRC plants and making ecological descriptions of them, taking into account trophic structure, habitat preferences, hydro preferences and phenology enables their use as bioindicators [136]. Jowett et al. [137] emphasized the role of the species profile of a given population as an important factor determining habitat maturity. One of the most important features of Carabidae allowing us to assess the ecological status of a given environment is food preferences. Although there is no doubt that carabids have a potential for pest control $[95,97,138-144]$, as well as weed seeds [145-148], there is remarkably little interest in the role they play in underpinning ecosystem services in bioenergy plantations. Rowe et al. [81] compared the processes of predation and litter decomposition in willow SRC and alternative land-uses: arable and set-aside. In the described bioassay, even though willow plants had the highest abundance and diversity of ground-dwelling arthropod predators, these factors had no detectable influence on predation rates. The reason for this was that the carabids were more active in cereal crops vs. SRC. As a result, the predation rates in the investigated plots did not differ between habitats. These observations were connected to the environmental factors, characteristic for each of the habitats. As it is known, these processes are 
inextricably linked to crop productivity and ecosystem stability; however, so far, our understanding of them in SRC crops is limited, and further investigations are required [81]. Therefore, it would be very valuable to carry out research work that combines the assessment of carabid communities and the ecosystem services provided by them and takes into account environmental factors. Unfortunately, there are currently no such publications.

\subsection{Carabidae Assemblages Structure}

A detailed description of Carabidae groupings allows for characterizing the habitat of a young willow plantation, rich mainly in eurytopic, poorly specialized species, as a temporary environment undergoing a dynamic development $[85,86]$. There was a large divergence gap between the dominant and the other dominance classes, which has also been proven by other researchers (Table 2, Figure 8) and is a factor indicating the instability of the population. It was shown that the most common group were open-field carabids, characteristic for adjacent areas (Table 2, Figures 4 and 5) Walerys et al. [86] claimed that this could be the result of the small size of the plantations studied. However, such a tendency was not visible for the older plantations, most of which had a higher share of forest species (Table 2, Figure 5). In most plantations mesophilic carabids dominated [85,86], Figure 10, as the most tolerant in terms of humidity requirements. Spring breeding carabids characteristic for newly colonized areas, dominated [86], Figure 7, while autumn and wintering beetle larvae, characteristic for older developmental stages [87] of stands, were absent on newly established plants. On the other hand, Kosewska et al. [85] indicated that the domination of one of the developmental Carabidae types in the studied area did not depend on the canopy, but was correlated with the study year [85]. Additionally, Kosewska et al. [85] showed that in older plants, beetles were less numerous than in the newly situated ones. This confirms the thesis that plantations in the initial period of the production cycle, as a transitional environment, constitute an attractive habitat for this type of species. The conducted study also showed that the number of large zoophages was higher in the older plants. This proves that the population is stable. Boháč et al. [110] investigated the impact of adjacent habitats on Carabidae and Staphylinidae population structure. As expected, the highest number of species was found on plots least affected by humans. For communities occurring in these plots, stenotopic species (e.g., Platynus assmilis) and large Carabidae species (e.g., Carabus hortensis hortensis, C. violaceus violaceus) were typical. Additionally, psychrophilic species characterized by winter activity were the best-represented group in these plots. Their research proved that the influence of anthropogenic factors was associated with an increased prevalence of eurytopic species, as well as an increased prevalence of species with summer imago activity.

On the other hand, forest species (e.g., Pterostichus oblongopunctatus), as well the protected Carabus scheidleri, were noted only in the fields adjacent to the forest, even though these were also fields with the highest anthropopressure. In addition, in studies evaluating carabidofauna in out of use plantations with old canopies [87], the presence of endangered and rare species was noticed. In these types of plants, the most numerous carabids were mesophilic species: Pterostichus melanarius, P. niger and hydrophilic Limodromus assimilis. P. niger and L. assimilis were classified as a forest species. Similarly, [88] reported that species preferring light forest or forest edges, such aslike Carabus convexus, as with species with higher humidity requirements such as the hygrophilous Panagaeus cruxmajor, are listed only for the longer rotations. Similar results obtained by other investigators [91] can suggest that these species are a regular component of carabidofauna in Central and Eastern Europe [87]. These results indicate the need for further research on the structure of the Carabidae population and prove that not the number of beetles in a given area is less important compared to their species profile.

\section{Conclusions with Remarks}

Energy willow and poplar plantations may increase the biodiversity of Carabidae beetles. Due to the lower use of pesticides, as well as the smaller number of agrotechnical treatments carried out, SRC can be a habitat which is more stable than annual crops, such as rape or wheat. However, energy plants also undergo dynamic changes, associated not only with the production cycle and canopy age, but also 
with the age of the plantation itself. This is especially important for forest species, which in older SRC may find conditions similar to those in their natural habitat. Nevertheless, the data describing forest species requirements and biodiversity in the SRC are still lacking. It is known, however, that even if poplar and willow plants cannot provide a permanent habitat for forest species, they can serve as ecological corridors, connecting isolated land patches, inhabited by populations of epigeic insects with low dispersal powers. Energy willow and poplar plantations, if they meet several conditions, can be used for agriculture, as well as serving as a refugium for animals inhabiting areas with a high risk of anthropopression

SRC plantations can provide carabids with breeding and shelter places, important especially if the adjacent areas of arable land are characterized by a strongly intensified agricultural production. Maintaining a stable population of Carabidae is recommended in the integrated agriculture model, the assumptions of which include reducing the negative impact on the natural environment and human life. Ground beetles play a crucial role in providing valuable ecosystem services. Moreover, their services concern not only the energy willow plantations themselves, but also contribute to the protection of adjacent annual crops. Carabidae communities are still not studied enough on SRC plants. This is the result of, on the one hand, the small number of studies that have been carried out on these crops, compared to, for example, rape cultivation, and on the other hand, the fact that many works were not translated into English and appear only in local periodicals. Therefore, assessment of ground beetle population on willow and poplar plants based on community structure is currently impossible. For energy willow, there is still a lack of complete data at the regional scale, which would enable us to create the ground beetle community model describing the level of naturalness of the habitat. According to this, further investigations should be done to estimate community structure to obtain additional data on the state of the habitat and diversity of species inhabiting poplar and willow plants.

Author Contributions: Conceptualization, N.S.P., S.Z.C. and M.J.S.; methodology, N.S.P., S.Z.C. and M.J.S.; validation, N.S.P., S.Z.C. and M.J.S.; formal analysis, N.S.P., S.Z.C. and M.J.S.; investigation, N.S.P.; resources, N.S.P., S.Z.C. and M.J.S.; data curation, N.S.P.; writing - original draft preparation, N.S.P.; writing-review and editing, N.S.P., S.Z.C. and M.J.S.; visualization, N.S.P.; supervision, S.Z.C. and M.J.S.; project administration, M.J.S.; funding acquisition, M.J.S.; All authors have read and agreed to the published version of the manuscript.

Funding: This paper was co-financed by the National (Polish) Centre for Research and Development (NCBiR), entitled "Environment, agriculture and forestry", project: BIOproducts from lignocellulosic biomass derived from MArginal land to fill the Gap in Current national bioeconomy, No. BIOSTRATEG3/344253/2/NCBR/2017.

Acknowledgments: Natalia Piotrowska is a recipient of a scholarship from the Programme Interdisciplinary Doctoral Studies in Bioeconomy (POWR.03.02.00-00-I034/16-00), which is funded by the European Social Funds.

Conflicts of Interest: The authors declare no conflict of interest.

\section{References}

1. Lindegaard, K.N.; Adams, P.W.R.; Holley, M.; Lamley, A.; Henriksson, A.; Larsson, S.; von Engelbrechten, H.-G.; Esteban Lopez, G.; Pisarek, M. Short rotation plantations policy history in Europe: Lessons from the past and recommendations for the future. Food Energy Secur. 2016, 5, 125-152. [CrossRef] [PubMed]

2. Volk, T.A.; Verwijst, T.; Tharakan, P.J.; Abrahamson, L.P.; White, E.H. Growing fuel: A sustainability assessment of willow biomass crops. Front. Ecol. Environ. 2004, 2, 411-418. [CrossRef]

3. Groom, M.J.; Gray, E.M.; Townsend, P.A. Biofuels and Biodiversity: Principles for Creating Better Policies for Biofuel Production. Conserv. Biol. 2008, 22, 602-609. [CrossRef]

4. Mohr, A.; Raman, S. Lessons from first-generation biofuels and implications for the sustainability appraisal of second-generation biofuels. Energy Policy 2013, 63, 114-122. [CrossRef] [PubMed]

5. Saladini, F.; Patrizi, N.; Pulselli, F.M.; Marchettini, N.; Bastianoni, S. Guidelines for emergy evaluation of first, second and third-generation biofuels. Renew. Sustain. Energy Rev. 2016, 66, 221-227. [CrossRef]

6. Liu, Y.; Xu, Y.; Zhang, F.; Yun, J.; Shen, Z. The impact of biofuel plantation on biodiversity: A review. Chin. Sci. Bull. 2014, 59, 4639-4651. [CrossRef]

7. Stolarski, M.; Szczukowski, S.; Tworkowski, J.; Krzyżaniak, M. Extensive Willow Biomass Production on Marginal Land. Pol. J. Environ. Stud. 2019, 28, 4359-4367. [CrossRef] 
8. Dauber, J.; Jones, M.B.; Stout, J.C. The impact of biomass crop cultivation on temperate biodiversity: Biomass crops and biodiversity. GCB Bioenergy 2010, 2, 289-309. [CrossRef]

9. Demirbas, M.F.; Balat, M.; Balat, H. Potential contribution of biomass to the sustainable energy development. Energy Convers. Manag. 2009, 50, 1746-1760. [CrossRef]

10. Jensen, J.K.; Holm, P.E.; Nejrup, J.; Larsen, M.B.; Borggaard, O.K. The potential of willow for remediation of heavy metal polluted calcareous urban soils. Environ. Pollut. 2009, 157, 931-937. [CrossRef]

11. Kacálková, L.; Tlustoš, P.; Száková, J. Phytoextraction of risk elements by willow and poplar trees. Int. J. Phytoremediation 2015, 17, 414-421. [CrossRef] [PubMed]

12. Pulford, I. Phytoremediation of heavy metal-contaminated land by trees-A review. Environ. Int. 2003, 29, 529-540. [CrossRef]

13. Ruttens, A.; Boulet, J.; Weyens, N.; Smeets, K.; Adriaensen, K.; Meers, E.; van Slycken, S.; Tack, F.; Meiresonne, L.; Thewys, T.; et al. Short rotation coppice culture of willows and poplars as energy crops on metal contaminated agricultural soils. Int. J. Phytoremediation 2011, 13 (Suppl. 1), 194-207. [CrossRef]

14. Riddell-Black, D. Heavy metal uptake by fast growing willow species. In A Biological Purification System: Conference and Workshop: Papers; Worldcat; Aronsson, P., Perttu, K., Eds.; Swedish University of Agricultural Sciences, Uppsala (Sweden) Department of Ecology and Environmental Research: Uppsala, Sweden, 1994; p. 231. ISSN 0282-6267.

15. Punshon, T.; Lepp, N.W.; Dickinson, N.M. Resistance to copper toxicity in some British willows. J. Geochem. Explor. 1995, 52, 259-266. [CrossRef]

16. Dickinson, N.M.; Punshon, T.; Hodkinson, R.B.; Lepp, N.W. Metal tolerance and accumulation in willows. In A Biological Purification System: Conference and Workshop: Papers; Worldcat; Aronsson, P., Perttu, K., Eds.; Swedish University of Agricultural Sciences, Uppsala (Sweden) Department of Ecology and Environmental Research: Uppsala, Sweden, 1994; p. 231. ISSN 0282-6267.

17. Greger, M.; Landberg, T. Use of Willow in Phytoextraction. Int. J. Phytoremediation 1999, 1, 115-123. [CrossRef]

18. Pilipović, A.; Zalesny, R.S.; Rončević, S.; Nikolić, N.; Orlović, S.; Beljin, J.; Katanić, M. Growth, physiology, and phytoextraction potential of poplar and willow established in soils amended with heavy-metal contaminated, dredged river sediments. J. Environ. Manag. 2019, 239, 352-365. [CrossRef]

19. Vysloužilová, M.; Tlustoš, P.; Száková, J.; Pavlíková, D. As, Cd, Pb and Zn uptake by Salix spp. clones grown in soils enriched by high loads of these elements. Plant Soil Environ. 2011, 49, 191-196. [CrossRef]

20. Yang, W.; Zhao, F.; Ding, Z.; Wang, Y.; Zhang, X.; Zhu, Z.; Yang, X. Variation of tolerance and accumulation to excess iron in 24 willow clones: Implications for phytoextraction. Int. J. Phytoremediation 2018, 20, 1284-1291. [CrossRef]

21. Dimitriou, I.; Mola-Yudego, B.; Aronsson, P.; Eriksson, J. Changes in Organic Carbon and Trace Elements in the Soil of Willow Short-Rotation Coppice Plantations. Bioenergy Res. 2012, 5, 563-572. [CrossRef]

22. Dimitriou, I.; Baum, C.; Baum, S.; Busch, G.; Schulz, U.; Kohn, J.; Lamersdorf, N.; Leinweber, P.; Aronsson, P.; Weih, M.; et al. The impact of Short Rotation Coppice (SRC) cultivation on the environment. Landbauforsch. Volkenrode 2009, 59, 159-162.

23. Klang-Westin, E.; Eriksson, J. Potential of Salix as phytoextractor for Cd on moderately contaminated soils. Plant Soil 2003, 249, 127-137. [CrossRef]

24. Aronsson, P.; Perttu, K. Willow vegetation filters for wastewater treatment and soil remediation combined with biomass production. For. Chron. 2001, 77, 293-299. [CrossRef]

25. Börjesson, P.; Berndes, G. The prospects for willow plantations for wastewater treatment in Sweden. Biomass Bioenergy 2006, 30, 428-438. [CrossRef]

26. Dimitriou, I.; Mola-Yudego, B.; Aronsson, P. Impact of Willow Short Rotation Coppice on Water Quality. Bioenergy Res. 2012, 5, 537-545. [CrossRef]

27. Urbaniak, M.; Wyrwicka, A.; Tołoczko, W.; Serwecińska, L.; Zieliński, M. The effect of sewage sludge application on soil properties and willow (Salix sp.) cultivation. Sci. Total Environ. 2017, 586, 66-75. [CrossRef]

28. Dimitriou, I.; Eriksson, J.; Adler, A.; Aronsson, P.; Verwijst, T. Fate of heavy metals after application of sewage sludge and wood-ash mixtures to short-rotation willow coppice. Environ. Pollut. 2006, 142, 160-169. [CrossRef] 
29. Mao, R.; Zeng, D.-H.; Hu, Y.-L.; Li, L.-J.; Yang, D. Soil organic carbon and nitrogen stocks in an age-sequence of poplar stands planted on marginal agricultural land in Northeast China. Plant Soil 2010, 332, 277-287. [CrossRef]

30. McIvor, I.R.; Douglas, G.B. Poplars and willows in hill country-Stabilising soils and storing carbon. Adv. Nutr. Manag. Gains Past Goals Future 2012, 25, 1-11.

31. Coleman, M.D.; Isebrands, J.G.; Tolsted, D.N.; Tolbert, V.R. Comparing Soil Carbon of Short Rotation Poplar Plantations with Agricultural Crops and Woodlots in North Central United States. Environ. Manag. 2004, 33. [CrossRef]

32. Mukherjee, A.; Coleman, M.D. Converting Conventional Agriculture to Poplar Bioenergy Crops: Soil Chemistry. Commun. Soil Sci. Plant Anal. 2020, 51, 364-379. [CrossRef]

33. Lockwell, J.; Guidi, W.; Labrecque, M. Soil carbon sequestration potential of willows in short-rotation coppice established on abandoned farm lands. Plant. Soil 2012, 360, 299-318. [CrossRef]

34. Langeveld, H.; Quist-Wessel, F.; Dimitriou, I.; Aronsson, P.; Baum, C.; Schulz, U.; Bolte, A.; Baum, S.; Köhn, J.; Weih, M.; et al. Assessing Environmental Impacts of Short Rotation Coppice (SRC) Expansion: Model Definition and Preliminary Results. Bioenergy Res. 2012, 5, 621-635. [CrossRef]

35. Acharya, B.S.; Blanco-Canqui, H. Lignocellulosic-based bioenergy and water quality parameters: A review. GCB Bioenergy 2018, 10, 504-533. [CrossRef]

36. Baum, C.; Leinweber, P.; Weih, M.; Lamersdorf, N.; Dimitriou, I. Effects of short rotation coppice with willows and poplar on soil ecology. Landbauforsch. vTI Agric. Res. 2009, 59, 183-196.

37. Weissteiner, C.J.; García-Feced, C.; Paracchini, M.L. A new view on EU agricultural landscapes: Quantifying patchiness to assess farmland heterogeneity. Ecol. Indic. 2016, 61, 317-327. [CrossRef]

38. Shortall, O.K. "Marginal land" for energy crops: Exploring definitions and embedded assumptions. Energy Policy 2013, 62, 19-27. [CrossRef]

39. Leather, S.R. "Ecological Armageddon"-More evidence for the drastic decline in insect numbers: Insect declines. Ann. Appl. Biol. 2018, 172, 1-3. [CrossRef]

40. Simmons, B.I.; Balmford, A.; Bladon, A.J.; Christie, A.P.; De Palma, A.; Dicks, L.V.; Gallego-Zamorano, J.; Johnston, A.; Martin, P.A.; Purvis, A.; et al. Worldwide insect declines: An important message, but interpret with caution. Ecol. Evol. 2019, 9, 3678-3680. [CrossRef]

41. Shortall, C.R.; Moore, A.; Smith, E.; Hall, M.J.; Woiwod, I.P.; Harrington, R. Long-term changes in the abundance of flying insects. Insect Conserv. Divers. 2009, 2, 251-260. [CrossRef]

42. Hallmann, C.A.; Sorg, M.; Jongejans, E.; Siepel, H.; Hofland, N.; Schwan, H.; Stenmans, W.; Müller, A.; Sumser, H.; Hörren, T.; et al. More than 75 percent decline over 27 years in total flying insect biomass in protected areas. PLoS ONE 2017, 12, e0185809. [CrossRef]

43. van Klink, R.; Bowler, D.E.; Gongalsky, K.B.; Swengel, A.B.; Gentile, A.; Chase, J.M. Meta-analysis reveals declines in terrestrial but increases in freshwater insect abundances. Science 2020, 368, 417-420. [CrossRef] [PubMed]

44. Sánchez-Bayo, F.; Wyckhuys, K.A.G. Worldwide decline of the entomofauna: A review of its drivers. Biol. Conserv. 2019, 232, 8-27. [CrossRef]

45. Bhattacharya, M.; Primack, R.B.; Gerwein, J. Are roads and railroads barriers to bumblebee movement in a temperate suburban conservation area? Biol. Conserv. 2003, 109, 37-45. [CrossRef]

46. Keller, I.; Nentwig, W.; Largiadèr, C.R. Recent habitat fragmentation due to roads can lead to significant genetic differentiation in an abundant flightless ground beetle: Differentiation due to habitat fragmentation. Mol. Ecol. 2004, 13, 2983-2994. [CrossRef]

47. Keller, I.; Excoffier, L.; Largiader, C.R. Estimation of effective population size and detection of a recent population decline coinciding with habitat fragmentation in a ground beetle. J. Evol. Biol. 2005, 18, 90-100. [CrossRef]

48. Goulson, D.; Nicholls, E.; Botias, C.; Rotheray, E.L. Bee declines driven by combined stress from parasites, pesticides, and lack of flowers. Science 2015, 347, 1255957. [CrossRef]

49. van Lexmond, M.B.; Bonmatin, J.-M.; Goulson, D.; Noome, D.A. Worldwide integrated assessment on systemic pesticides: Global collapse of the entomofauna: Exploring the role of systemic insecticides. Environ. Sci. Pollut. Res. 2015, 22, 1-4. [CrossRef]

50. Stokstad, E. Field Research on Bees Raises Concern about Low-Dose Pesticides. Science 2012, $335,1555$. [CrossRef] 
51. Wallisdevries, M.F.; Van Swaay, C.A.M. Global warming and excess nitrogen may induce butterfly decline by microclimatic cooling. Glob. Chang. Biol. 2006, 12, 1620-1626. [CrossRef]

52. Müller-Kroehling, S.; Jantsch, M.; Fischer, H.; Fischer, A. Modelling the effects of global warming on the ground beetle (Coleoptera: Carabidae) fauna of beech forests in Bavaria, Germany. Eur. J. Entomol. 2014, 111, 35-49. [CrossRef]

53. Blanco, H.; Lal, R. Principles of Soil Conservation and Management; Springer: Dordrecht, The Netherlands, 2010; ISBN 978-1-4020-8709-7.

54. Fry, D.A.; Slater, F.M. Early rotation short rotation willow coppice as a winter food resource for birds. Biomass Bioenergy 2011, 35, 2545-2553. [CrossRef]

55. Sage, R.B.; Robertson, P.A. Factors affecting songbird communities using new short rotation coppice habitats in spring. Bird Study 1996, 43, 201-213. [CrossRef]

56. Londo, M.; Dekker, J.; Terkeurs, W. Willow short-rotation coppice for energy and breeding birds: An exploration of potentials in relation to management. Biomass Bioenergy 2005, 28, 281-293. [CrossRef]

57. Sage, R.; Cunningham, M.; Boatman, N. Birds in willow short-rotation coppice compared to other arable crops in central England and a review of bird census data from energy crops in the UK: Birds in short-rotation coppice. IBIS 2006, 148, 184-197. [CrossRef]

58. Riffell, S.; Verschuyl, J.; Miller, D.; Wigley, T.B. A meta-analysis of bird and mammal response to short-rotation woody crops: Meta-analysis of bird and mammal response. GCB Bioenergy 2011, 3, 313-321. [CrossRef]

59. Berg, Å. Breeding birds in short-rotation coppices on farmland in central Sweden-The importance of Salix height and adjacent habitats. Agric. Ecosyst. Environ. 2002, 90, 265-276. [CrossRef]

60. Christian, D.P.; Hoffman, W.; Hanowski, J.M.; Niemi, G.J.; Beyea, J. Bird and mammal diversity on woody biomass plantations in North America. In Biomass and Bioenergy; Elsevier: Amsterdam, The Netherlands, 1998.

61. Campbell, S.P.; Frair, J.L.; Gibbs, J.P.; Volk, T.A. Use of short-rotation coppice willow crops by birds and small mammals in central New York. Biomass Bioenergy 2012, 47, 342-353. [CrossRef]

62. Baxter, D.A.; Sage, R.B.; Hall, D.O. A methodology for assessing gamebird use of short rotation coppice. Biomass Bioenergy 1996, 10, 301-306. [CrossRef]

63. Dhondt, A.A.; Wrege, P.H.; Sydenstricker, K.V.; Cerretani, J. Clone preference by nesting birds in short-rotation coppice plantations in central and western New York. Biomass Bioenergy 2004, 27, 429-435. [CrossRef]

64. Dhondt, A.A.; Wrege, P.H.; Cerretani, J.; Sydenstricker, K.V. Avian species richness and reproduction in short-rotation coppice habitats in central and western New York. Bird Study 2007, 54, 12-22. [CrossRef]

65. Göransson, G. Bird fauna of cultivated energy shrub forests at different heights. Biomass Bioenergy 1994, 6, 49-52. [CrossRef]

66. Hanowski, J.M.; Niemi, G.J.; Christian, D.C. Influence of Within-Plantation Heterogeneity and Surrounding Landscape Composition on Avian Communities in Hybrid Poplar Plantations. Influencia de la Heterogeneidad Intra-plantacion y de la Composicion del Paisaje Circundante Sobre Comunidades de Aves en Plantaciones de Alamo Hibrido. Conserv. Biol. 1997, 11, 936-944. [CrossRef]

67. Wilson, J. The breeding bird community of willow scrub at Leighton Moss, Lancashire. Bird Study 1978, 25, 239-244. [CrossRef]

68. Bergström, R.; Guillet, C. Summer browsing by large herbivores in short-rotation willow plantations. Biomass Bioenergy 2002, 23, 27-32. [CrossRef]

69. Christian, D.P. Wintertime use of hybrid poplar plantations by deer and medium-sized mammals in the midwestern U.S. Biomass Bioenergy 1997, 12, 35-40. [CrossRef]

70. Christian, D.P.; Niemi, G.J.; Hanowski, J.M.; Collins, P. Perspectives on biomass energy tree plantations and changes in habitat for biological organisms. Biomass Bioenergy 1994, 6, 31-39. [CrossRef]

71. Giordano, M.; Alberto, M. Use by small mammals of short-rotation plantations in relation to their structure and isolation. Hystrix Ital. J. Mammal. 2010, 20. [CrossRef]

72. Moser, B.W.; Pipas, M.J.; Witmer, G.W.; Engeman, R.M. Small mammal use of hybrid poplar plantations relative to stand age. Northwest. Sci. 2002, 76, 158-165.

73. Björkman, C.; Bommarco, R.; Eklund, K.; Höglund, S. Harvesting disrupts biological control of herbivores in a short-rotation coppice system. Ecol. Appl. 2004, 14, 1624-1633. [CrossRef]

74. Langer, V. The potential of leys and short rotation coppice hedges as reservoirs for parasitoids of cereal aphids in organic agriculture. Agric. Ecosyst. Environ. 2001, 87, 81-92. [CrossRef] 
75. Minor, M.; Norton, R. Erratum: Effects of soil amendments on assemblages of soil mites (Acari: Oribatida, Mesostigmata) in short-rotation willow plantings in central New York. Can. J. For. Res. 2004, 34, 1417-1425. [CrossRef]

76. Minor, M.A.; Volk, T.A.; Norton, R.A. Effects of site preparation techniques on communities of soil mites (Acari: Oribatida, Acari: Gamasida) under short-rotation forestry plantings in New York, USA. Appl. Soil Ecol. 2004, 25, 181-192. [CrossRef]

77. Mueller, M.; Klein, A.-M.; Scherer-Lorenzen, M.; Nock, C.A.; Staab, M. Tree genetic diversity increases arthropod diversity in willow short rotation coppice. Biomass Bioenergy 2018, 108, 338-344. [CrossRef]

78. Mueller, A.L.; Dauber, J. Hoverflies (Diptera: Syrphidae) benefit from a cultivation of the bioenergy crop Silphium perfoliatum L. (Asteraceae) depending on larval feeding type, landscape composition and crop management. Agric. For. Entomol. 2016, 18, 419-431. [CrossRef]

79. Peacock, L.; Batley, J.; Dungait, J.; Barker, J.H.A.; Powers, S.; Karp, A. A comparative study of interspecies mating of Phratora vulgatissima and P. vitellinae using behavioural tests and molecular markers. Entomol. Exp. Appl. 2004, 110, 231-241. [CrossRef]

80. Peacock, L.; Herrick, S.; Brain, P. Spatio-temporal dynamics of willow beetle (Phratora vulgatissima) in short-rotation coppice willows grown as monocultures or a genetically diverse mixture. Agric. For. Entomol. 1999, 1, 287-296. [CrossRef]

81. Rowe, R.L.; Goulson, D.; Doncaster, C.P.; Clarke, D.J.; Taylor, G.; Hanley, M.E. Evaluating ecosystem processes in willow short rotation coppice bioenergy plantations. GCB Bioenergy 2013, 5, 257-266. [CrossRef]

82. Sage, R.B.; Tucker, K. The distribution of Phratora vulgatissima (Coleoptera: Chrysomelidae) on cultivated willows in Britain and Ireland. For. Pathol 1998, 28, 289-296. [CrossRef]

83. Sage, R.B.; Fell, D.; Tucker, K.; Sotherton, N.W. Post hibernation dispersal of three leaf-eating beetles (Coleoptera: Chrysomelidae) colonising cultivated willows and poplars. Agric. For. Entomol. 1999, 1, 61-70. [CrossRef]

84. Reddersen, J. SRC-willow (Salixviminalis) as a resource for flower-visiting insects. Biomass Bioenergy 2001, 20, 171-179. [CrossRef]

85. Kosewska, A.; Nietupski, M.; Agnieszka, L.-D.; Dolores, C. Biegaczowate (Col. Carabidae) zasiedlające uprawy wierzby krzewiastej w okolicach Olsztyna. Prog. Plant. Prot. 2010, 50, 1504-1510.

86. Walerys, G.; Kosewska, A.; Wojciech, S. Uprawa wierzby krzewiastej Salix spp. miejscem bytowania drapieżnych biegaczowatych Carabidae. Fragm. Agron. 2008, XXV, 158-169.

87. Konieczna, K.; Melke, A.; Olbrycht, T. Unexploited willow's plantation (Salix viminalis) as a reservoir of epigeic ground beetles (Col., Carabidae) and rove beetles (Col., Staphylinidae). Prog. Plant. Prot. 2013, 53, 319-326.

88. Weger, J.; Vávrová, K.; Kašparová, L.; Bubeník, J.; Komárek, A. The influence of rotation length on the biomass production and diversity of ground beetles (Carabidae) in poplar short rotation coppice. Biomass Bioenergy 2013, 54, 284-292. [CrossRef]

89. Müller-Kroehling, S.; Hohmann, G.; Helbig, C.; Liesebach, M.; Lübke-Al Hussein, M.; Al Hussein, I.A.; Burmeister, J.; Jantsch, M.C.; Zehlius-Eckert, W.; Müller, M. Biodiversity functions of short rotation coppice stands—Results of a meta study on ground beetles (Coleoptera: Carabidae). Biomass Bioenergy 2020, 132, 105416. [CrossRef]

90. Burel, F. Landscape structure effects on carabid beetles spatial patterns in western France. Landsc. Ecol 1989, 2, 215-226. [CrossRef]

91. Czerniakowski, Z.W.; Olbrycht, T. Ground beetles (Coleoptera, Carabidae) in the short-rotation biomass plantations. Zesz. Nauk. Południowo Wschod. Oddziału Pol. Tow. Inżynierii Ekol. Z Siedziba W Rzesz. I Pol. Tow. Glebozn. Oddziat W Rzesz. 2009, 11,39-42.

92. Allegro, G.; Sciaky, R. Assessing the potential role of ground beetles (Coleoptera, Carabidae) as bioindicators in poplar stands, with a newly proposed ecological index (FAI). For. Ecol. Manag. 2003, 175, 275-284. [CrossRef]

93. Brauner, O.; Schulz, U. Ground beetle communities (Carabidae) on short rotation coppices and adjacent crop areas-Investigations in Saxony and Brandenburg. Entomol. Blaetter Fuer Biol. Und Syst. Der Kaefer 2011, 107, $31-64$. 
94. Sage, R.; Cunningham, M.; Haughton, A.J.; Mallott, M.D.; Bohan, D.A.; Riche, A.; Karp, A. The environmental impacts of biomass crops: Use by birds of miscanthus in summer and winter in southwestern England: Birds in miscanthus. IBIS 2010, 152, 487-499. [CrossRef]

95. Holland, J. Carabid Beetles: Their Ecology, Survival and Use in Agroecosystems. In The Agroecology of Carabid Beetles; Intercept: New York, NY, USA, 2002; pp. 1-40. ISBN 1-898298-76-9.

96. Schulz, U.; Brauner, O.; Gruss, H. Animal diversity on short-rotation coppices-A review. Vti Agric. Res. 2009, 3, 171-182.

97. Kromp, B. Carabid beetles in sustainable agriculture: A review on pest control efficacy, cultivation impacts and enhancement. Agric. Ecosyst. Environ. 1999, 74, 187-228. [CrossRef]

98. Regulska, E. Carabidae in landscape research on the basis on literature, 2005-2008. Pol. J. Environ. Stud. 2011, 20, 733-741.

99. Kotze, D.J.; Brandmayr, P.; Casale, A.; Dauffy-Richard, E.; Dekoninck, W.; Koivula, M.J.; Lövei, G.L.; Mossakowski, D.; Noordjik, J.; Paarmann, W.; et al. Forty years of carabid beetle research in Europe-From taxonomy, biology, ecology and population studies to bioindication, habitat assessment and conservation. ZooKeys 2011, 100, 55-148. [CrossRef]

100. Bianchi, F.J.J.A.; Booij, C.J.H.; Tscharntke, T. Sustainable pest regulation in agricultural landscapes: A review on landscape composition, biodiversity and natural pest control. Proc. R. Soc. B 2006, 273, 1715-1727. [CrossRef]

101. Thiele, H.-U. Carabid Beetles in Their Environments: A Study on Habitat Selection by Adaptations in Physiology and Behaviour; Springer: Berlin/Heidelberg, Germany, 1977; ISBN 978-3-642-81154-8.

102. Szyszko, J. Próba Waloryzacji Środowisk Leśnych Przy Pomocy Biegaczowatych (Carabidea, Col.) Waloryzacja Ekosystemów Leśnych Metodami Bioidnykacyjnymi.; SGGW: Warszawa, Poland, 1997.

103. Kulkarmi, S.; Dosdall, L.; Willenborg, C. The Role of Ground Beetles (Coleoptera: Carabidae) in Weed Seed Consumption: A Review. Weed Sci. 2015, 63, 150304133636004. [CrossRef]

104. Frei, B.; Guenay, Y.; Bohan, D.A.; Traugott, M.; Wallinger, C. Molecular analysis indicates high levels of carabid weed seed consumption in cereal fields across Central Europe. J. Pest. Sci 2019, 92, 935-942. [CrossRef]

105. Huruk, S. Comparison of structure of carabid (Coleoptera: Carabidae) communities of hay meadows and adjacent cultivated fields. Wiadomości Entomol. 2006, 25, 9-32.

106. Nakamura, M.; Kagata, H.; Ohgushi, T. Trunk cutting initiates bottom-up cascades in a tri-trophic system: Sprouting increases biodiversity of herbivorous and predaceous arthropods on willows. Oikos 2006, 113, 259-268. [CrossRef]

107. Baum, S.; Weih, M.; Busch, G.; Kroiher, F.; Bolte, A. The impact of Short Rotation Coppice plantations on phytodiversity. Landbauforsch Volkenrode 2009, 59, 163-170.

108. Briones, M.J.I.; Elias, D.M.O.; Grant, H.K.; McNamara, N.P. Plant identity control on soil food web structure and C transfers under perennial bioenergy plantations. Soil Biol. Biochem. 2019, 138, 107603. [CrossRef]

109. Kahle, P.; Janssen, M. Impact of short-rotation coppice with poplar and willow on soil physical properties. J. Plant Nutr. Soil Sci. 2020, 183, 119-128. [CrossRef]

110. Boháč, J.; Celjak, I.; Moudrý, J.; Kohout, P.; Wotavová, K. Communities of beetles in plantations of fast growing plant species for energetic purposes. Entomol.Rom. 2007, 12, 213-221.

111. Sotherton, N.W. The distribution and abundance of predatory Coleoptera overwintering in field boundaries. Ann. Appl. Biol. 1985, 106, 17-21. [CrossRef]

112. Stolarski, M.J.; Szczukowski, S.; Tworkowski, J.; Klasa, A. Yield, energy parameters and chemical composition of short-rotation willow biomass. Ind. Crop. Prod. 2013, 46, 60-65. [CrossRef]

113. Graham, J.B.; Nassauer, J.I. Wild bee abundance in temperate agroforestry landscapes: Assessing effects of alley crop composition, landscape configuration, and agroforestry area. Agroforest Syst 2019, 93, 837-850. [CrossRef]

114. Vanbeveren, S.; Ceulemans, R. Biodiversity in short-rotation coppice. Renew. Sustain. Energy Rev. 2019, 111, 34-43. [CrossRef]

115. Damschen, E.I. Landscape Corridors. In Encyclopedia of Biodiversity; Elsevier: Amsterdam, The Netherlands, 2013; pp. 467-475. ISBN 978-0-12-384720-1.

116. Rogan, J.E.; Lacher, T.E. Impacts of Habitat Loss and Fragmentation on Terrestrial Biodiversity. In Reference Module in Earth Systems and Environmental Sciences; Elsevier: Amsterdam, The Netherlands, 2018; p. B9780124095489110000. ISBN 978-0-12-409548-9. 
117. Fahrig, L. Why do several small patches hold more species than few large patches? Glob. Ecol. Biogeogr. 2020, 29, 615-628. [CrossRef]

118. Rybicki, J.; Abrego, N.; Ovaskainen, O. Habitat fragmentation and species diversity in competitive communities. Ecol. Lett. 2020, 23, 506-517. [CrossRef]

119. Tjørve, E. How to resolve the SLOSS debate: Lessons from species-diversity models. J. Theor. Biol. 2010, 264, 604-612. [CrossRef]

120. Cartwright, J. Ecological islands: Conserving biodiversity hotspots in a changing climate. Front. Ecol. Env. 2019, fee.2058. [CrossRef]

121. Losos, J.B.; Ricklefs, R.E.; MacArthur, R.H. The Theory of Island Biogeography Revisited; Princeton University Press: Princeton, NJ, USA, 2010; ISBN 978-1-4008-3192-0.

122. MacArthur, R.H.; Wilson, E.O. The Theory of Island Biogeography; Princeton University Press: Princeton, NJ, USA, 2001; ISBN 978-0-691-08836-5.

123. Banaszak, J. Wyspy Środowiskowe: Bioróżnorodność i Próby Typologii; Akademia Bydgoska im. Kazimierza Wielkiego: Bydgoszcz, Poland, 2002; ISBN 978-83-7096-459-7.

124. Warren, B.H.; Simberloff, D.; Ricklefs, R.E.; Aguilée, R.; Condamine, F.L.; Gravel, D.; Morlon, H.; Mouquet, N.; Rosindell, J.; Casquet, J.; et al. Islands as model systems in ecology and evolution: Prospects fifty years after MacArthur-Wilson. Ecol. Lett. 2015, 18, 200-217. [CrossRef] [PubMed]

125. Helmus, M.R.; Behm, J.E. Island Biogeography Revisited. In Reference Module in Earth Systems and Environmental Sciences; Elsevier: Amsterdam, The Netherlands, 2019; ISBN 978-0-12-409548-9.

126. Corbet, S.A. Insects, plants and succession: Advantages of long-term set-aside. Agric. Ecosyst. Environ. 1995, 53, 201-217. [CrossRef]

127. Staley, J.T.; Sparks, T.H.; Croxton, P.J.; Baldock, K.C.R.; Heard, M.S.; Hulmes, S.; Hulmes, L.; Peyton, J.; Amy, S.R.; Pywell, R.F. Long-term effects of hedgerow management policies on resource provision for wildlife. Biol. Conserv. 2012, 145, 24-29. [CrossRef]

128. Wehling, S.; Diekmann, M. Importance of hedgerows as habitat corridors for forest plants in agricultural landscapes. Biol. Conserv. 2009, 142, 2522-2530. [CrossRef]

129. Londo, M.; Roose, M.; Dekker, J.; de Graaf, H. Willow short-rotation coppice in multiple land-use systems: Evaluation of four combination options in the Dutch context. Biomass Bioenergy 2004, 27, 205-221. [CrossRef]

130. Homburg, K.; Drees, C.; Boutaud, E.; Nolte, D.; Schuett, W.; Zumstein, P.; Ruschkowski, E.; Assmann, T. Where have all the beetles gone? Long-term study reveals carabid species decline in a nature reserve in Northern Germany. Insect Conserv. Divers. 2019, icad.12348. [CrossRef]

131. Maes, D.; Titeux, N.; Hortal, J.; Anselin, A.; Decleer, K.; De Knijf, G.; Fichefet, V.; Luoto, M. Predicted insect diversity declines under climate change in an already impoverished region. J. Insect Conserv. 2010, 14, 485-498. [CrossRef]

132. Wilson, R.J.; Maclean, I.M.D. Recent evidence for the climate change threat to Lepidoptera and other insects. J. Insect Conserv. 2011, 15, 259-268. [CrossRef]

133. Wagner, D.L. Insect Declines in the Anthropocene. Annu. Rev. Entomol. 2020, 65, 457-480. [CrossRef]

134. Didham, R.K.; Basset, Y.; Collins, C.M.; Leather, S.R.; Littlewood, N.A.; Menz, M.H.M.; Müller, J.; Packer, L.; Saunders, M.E.; Schönrogge, K.; et al. Interpreting insect declines: Seven challenges and a way forward. Insect Conserv Divers. 2020, 13, 103-114. [CrossRef]

135. Forister, M.L.; Pelton, E.M.; Black, S.H. Declines in insect abundance and diversity: We know enough to act now. Conserv. Sci Pr. 2019, 1. [CrossRef]

136. Eyre, M.D.; McMillan, S.D.; Critchley, C.N.R. Ground beetles (Coleoptera, Carabidae) as indicators of change and pattern in the agroecosystem: Longer surveys improve understanding. Ecol. Indic. 2016, 68, 82-88. [CrossRef]

137. Jowett, K.; Milne, A.E.; Metcalfe, H.; Hassall, K.L.; Potts, S.G.; Senapathi, D.; Storkey, J. Species matter when considering landscape effects on carabid distributions. Agric. Ecosyst. Environ. 2019, 285, 106631. [CrossRef]

138. Zaller, J.G.; Moser, D.; Drapela, T.; Frank, T. Ground-dwelling predators can affect within-field pest insect emergence in winter oilseed rape fields. BioControl 2009, 54, 247-253. [CrossRef]

139. Suenaga, H.; Hamamura, T. Occurrence of carabid beetles (Coleoptera: Carabidae) in cabbage fields and their possible impact on lepidopteran pests. Appl. Entomol. Zool. 2001, 36, 151-160. [CrossRef]

140. Vichitbandha, P.; Wise, D.H. A field experiment on the effectiveness of spiders and carabid beetles as biocontrol agents in soybean. Agric. For. Ent 2002, 4, 31-38. [CrossRef] 
141. Warner, D.J.; Allen-Williams, L.J.; Warrington, S.; Ferguson, A.W.; Williams, I.H. Implications for conservation biocontrol of spatio-temporal relationships between carabid beetles and coleopterous pests in winter oilseed rape. Agric. For. Entomol. 2008, 10, 375-387. [CrossRef]

142. Schlein, O.; Buechs, W. Approaches to assess the importance of carnivorous beetles as predators of oilseed rape pests. Iobc Wprs Bull. 2004, 27, 289-292.

143. Schmidt, M.H.; Lauer, A.; Purtauf, T.; Thies, C.; Schaefer, M.; Tscharntke, T. Relative importance of predators and parasitoids for cereal aphid control. Proc. R. Soc. Lond. B 2003, 270, 1905-1909. [CrossRef]

144. Woodcock, B.A.; Harrower, C.; Redhead, J.; Edwards, M.; Vanbergen, A.J.; Heard, M.S.; Roy, D.B.; Pywell, R.F. National patterns of functional diversity and redundancy in predatory ground beetles and bees associated with key UK arable crops. J. Appl. Ecol. 2014, 51, 142-151. [CrossRef]

145. Honek, A.; Martinkova, Z.; Jarosik, V. Ground beetles (Carabidae) as seed predators. Eur. J. Entomol. 2003, 100, 531-544. [CrossRef]

146. Menalled, F.D.; Smith, R.G.; Dauer, J.T.; Fox, T.B. Impact of agricultural management on carabid communities and weed seed predation. Agric. Ecosyst. Environ. 2007, 118, 49-54. [CrossRef]

147. Sasakawa, K. Field Observations of Climbing Behavior and Seed Predation by Adult Ground Beetles (Coleoptera: Carabidae) in a Lowland Area of the Temperate Zone: Table 1. Environ. Entomol. 2010, 39, 1554-1560. [CrossRef] [PubMed]

148. Pannwitt, H.; Westerman, P.R.; de Mol, F.; Selig, C.; Gerowitt, B. Biological control of weed patches by seed predators; responses to seed density and exposure time. Biol. Control. 2017, 108, 1-8. [CrossRef]

Publisher's Note: MDPI stays neutral with regard to jurisdictional claims in published maps and institutional affiliations.

(C) 2020 by the authors. Licensee MDPI, Basel, Switzerland. This article is an open access article distributed under the terms and conditions of the Creative Commons Attribution (CC BY) license (http://creativecommons.org/licenses/by/4.0/). 